\title{
Impact of climate change on Antarctic krill
}

\author{
H. Flores ${ }^{1,2, *}$, A. Atkinson, S. Kawaguchi, B. A. Krafft, G. Milinevsky, S. Nicol, \\ C. Reiss, G. A. Tarling, R. Werner, E. Bravo Rebolledo, V. Cirelli, J. Cuzin-Roudy, \\ S. Fielding, J. J. Groeneveld, M. Haraldsson, A. Lombana, E. Marschoff, B. Meyer, \\ E. A. Pakhomov, E. Rombolá, K. Schmidt, V. Siegel, M. Teschke, H. Tonkes, J. Y. \\ Toullec, P. N. Trathan, N. Tremblay, A. P. Van de Putte, J. A. van Franeker, T. Werner ${ }^{\S}$ \\ ${ }^{1}$ Institute for Marine Resources and Ecosystem Studies (IMARES), 1790 AD Den Burg (Texel), The Netherlands \\ ${ }^{2}$ Alfred Wegener Institute for Polar and Marine Research, 27570 Bremerhaven, Germany
}

ABSTRACT: Antarctic krill Euphausia superba (hereafter 'krill') occur in regions undergoing rapid environmental change, particularly loss of winter sea ice. During recent years, harvesting of krill has increased, possibly enhancing stress on krill and Antarctic ecosystems. Here we review the overall impact of climate change on krill and Antarctic ecosystems, discuss implications for an ecosystem-based fisheries management approach and identify critical knowledge gaps. Sea ice decline, ocean warming and other environmental stressors act in concert to modify the abundance, distribution and life cycle of krill. Although some of these changes can have positive effects on krill, their cumulative impact is most likely negative. Recruitment, driven largely by the winter survival of larval krill, is probably the population parameter most susceptible to climate change. Predicting changes to krill populations is urgent, because they will seriously impact Antarctic ecosystems. Such predictions, however, are complicated by an intense inter-annual variability in recruitment success and krill abundance. To improve the responsiveness of the ecosystem-based management approach adopted by the Commission for the Conservation of Antarctic Marine Living Resources (CCAMLR), critical knowledge gaps need to be filled. In addition to a better understanding of the factors influencing recruitment, management will require a better understanding of the resilience and the genetic plasticity of krill life stages, and a quantitative understanding of under-ice and benthic habitat use. Current precautionary management measures of CCAMLR should be maintained until a better understanding of these processes has been achieved.

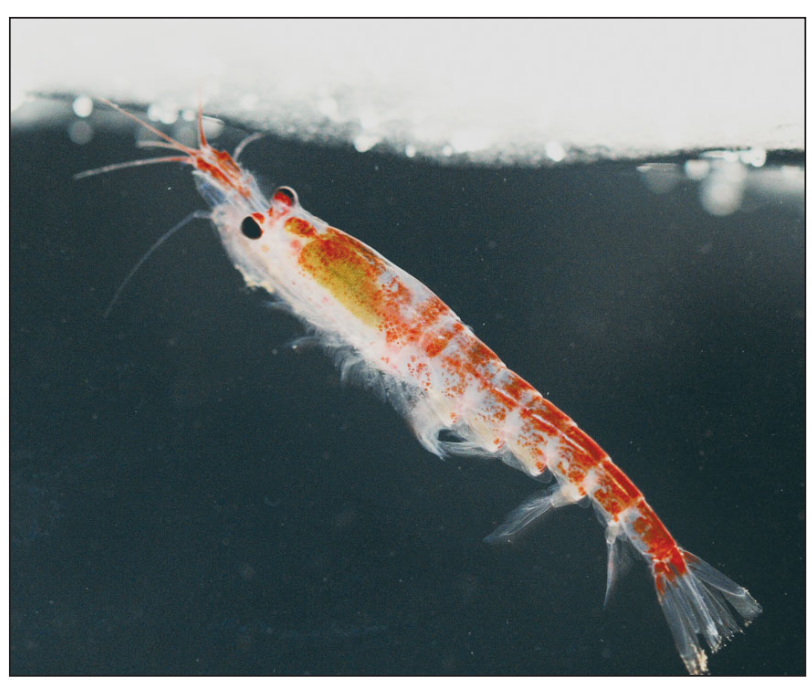

Antarctic krill Euphausia superba under a piece of sea ice in an aquarium.

Photo: Jan Andries van Franeker

KEY WORDS: Euphausia superba - Climate change · Sea ice $\cdot$ Ocean acidification $\cdot$ UV radiation $\cdot$ Fisheries management $\cdot$ CCAMLR $\cdot$ Southern Ocean

$$
\begin{gathered}
\text { Resale or republication not permitted without } \\
\text { written consent of the publisher }
\end{gathered}
$$

\section{INTRODUCTION}

The Southern Ocean habitat of Antarctic krill Euphausia superba (hereafter 'krill') is subject to ongoing environmental changes, such as sea ice decline (Stammerjohn et al. 2008), temperature rise 
A

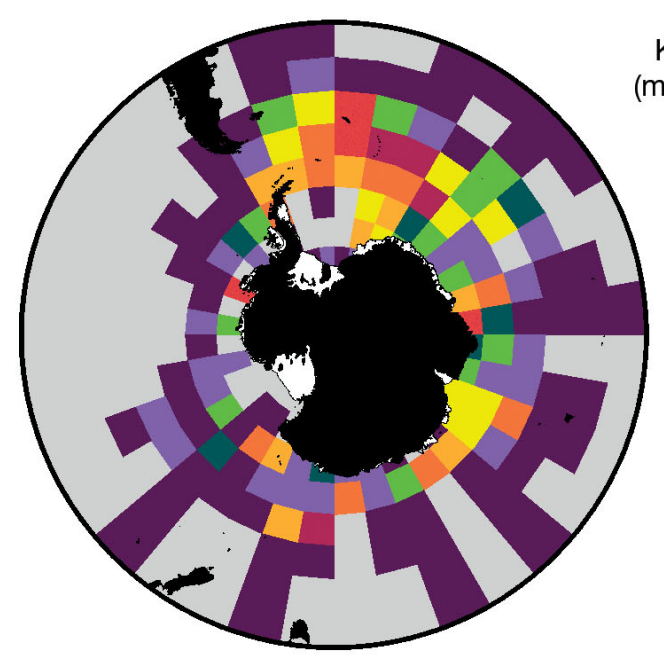

Krill distribution

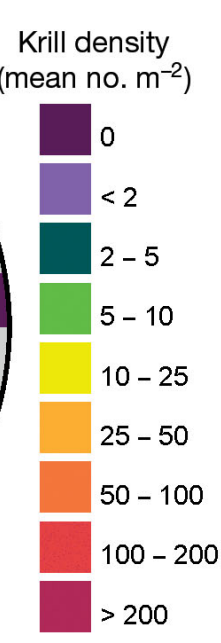

B

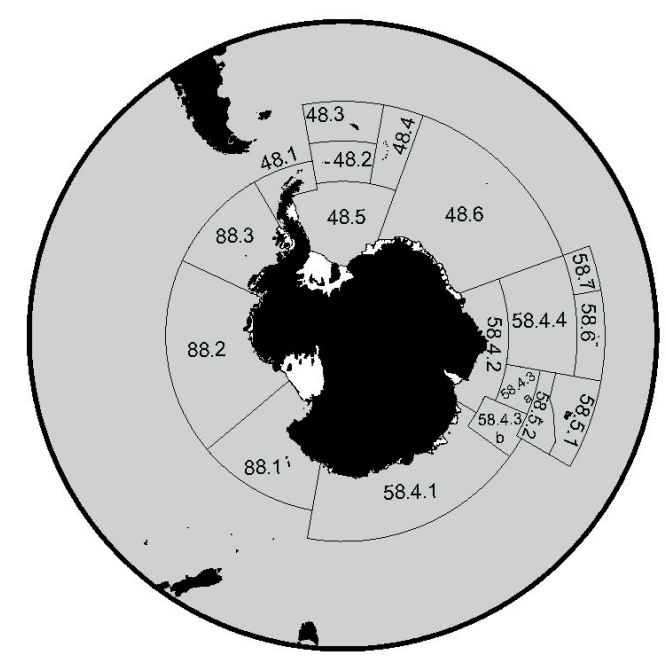

C

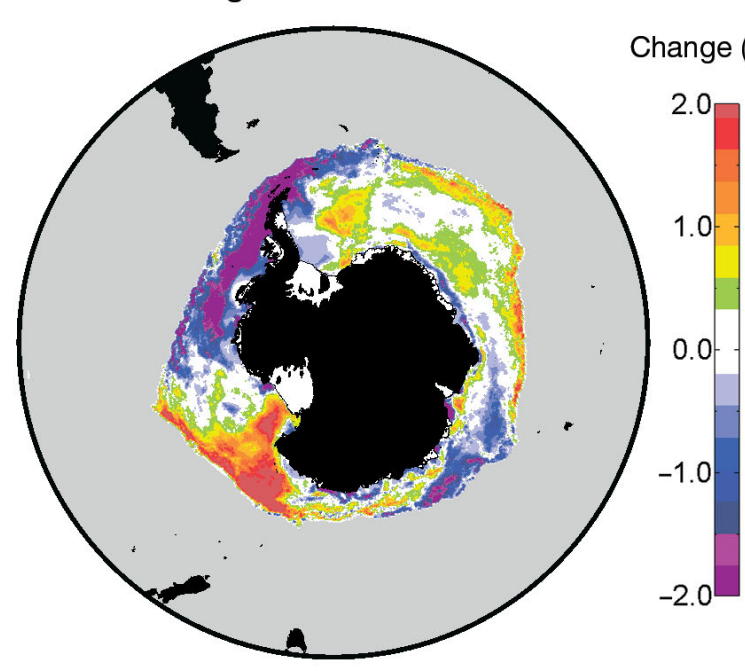

D

D Change in midwater temperatures

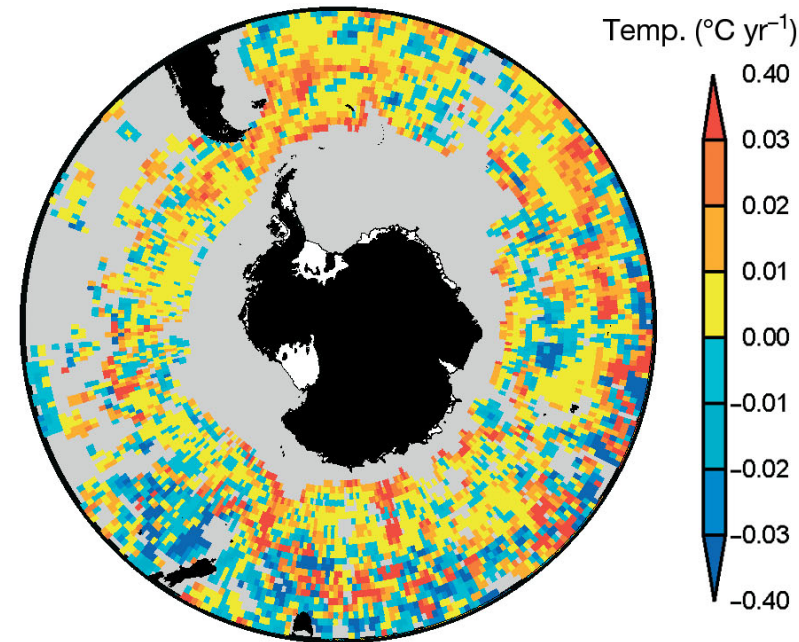

Fig. 1. (A) Circumpolar distribution of post-larval Antarctic krill (re-drawn from Atkinson et al. 2008). The plot shows arithmetic mean krill densities (ind. $\mathrm{m}^{-2}$ ) within each $5^{\circ}$ latitude by $10^{\circ}$ longitude grid cell derived from KRILLBASE. (B) CCAMLR convention area, with FAO statistical subareas 48.1 to 88.3. (C) Trends of change in ice season duration between 1979 and 2006 in $\mathrm{d} \mathrm{yr}^{-1}$ (provided by E. Maksym, British Antarctic Survey). Trends were calculated from satellite-based daily sea ice concentration data provided by the National Snow and Ice Data Center (University of Colorado at Boulder, http://nsidc.org), using the methodology described by Stammerjohn et al. (2008). (D) Trend of midwater ocean temperature change during the period 1930 to 2000 in ${ }^{\circ} \mathrm{C} \mathrm{yr}^{-1}$ (modified from Gille 2002, with permission). The analysis was based on archived shipboard measurements (1930-1990) and Autonomous Lagrangian Circulation Explorer (ALACE) float data (1990-2000) from 700 to $1100 \mathrm{~m}$ depth (@ American Association for the Advancement of Science 2002)

(Gille 2002) and ocean acidification (Orr et al. 2005). Rates of warming and sea ice loss are fastest in the southwest (SW) Atlantic sector, thus affecting key nursery habitats and feeding grounds of krill (Fig. 1A). These and other environmental changes are considered manifestations of the post-19th century anthropogenic carbon dioxide $\left(\mathrm{CO}_{2}\right)$ surplus (IPCC 2007), here summarised in the term 'climate change'. In addition, the commercial catch of krill has increased, in part as a consequence of new, efficient fishing techniques and the development of new products and markets between 2008 and the present (Nicol et al. 2012).

Recently, concern was expressed by several scientists about the future sustainability of krill harvesting under the cumulative pressure of climate change and fisheries (Jacquet et al. 2010, Schiermeier 2010). Such concern has been initiated by reports of a 
decrease in krill abundance in the SW Atlantic sector, paralleled by a decline in winter sea ice coverage during the last quarter of the 20th century (Atkinson et al. 2004), and declines in a number of krill-dependent predators (e.g. Trivelpiece et al. 2011). Furthermore, evidence is increasing that krill fulfil complex roles in ecosystem feedback loops through grazing and nutrient recycling (Tovar-Sanchez et al. 2007, Whitehouse et al. 2009, Nicol et al. 2010, Schmidt et al. 2012).

Because Antarctic krill populations and marine ecosystems are responding to climate change, resource and conservation management in the Southern Ocean will need to become much more adaptive. Conservation of Southern Ocean ecosystems falls under the responsibility of the Convention for the Conservation of Antarctic Marine Living Resources (CCAMLR), which was established in 1982 (Fig. 1B). As part of the Antarctic Treaty system, CCAMLR consists of 24 member countries plus the European Union. The aim of the Convention is to conserve Antarctic marine life and, at the same time, allow for the rational use of marine living resources (CCAMLR 1982).

A multi-national group of experts on krill and Antarctic environmental sciences met at a scientific workshop on the island Texel (The Netherlands) from 11 to 15 April 2011 to produce an up-to-date evaluation of present scientific knowledge on the impacts of climate change and increasing human exploitation on krill. Here we present the conclusions reached during this workshop, focusing on major agents of climate change, such as sea ice loss, ocean warming and ocean acidification, as well as recent developments in the krill fishery. The main objective of this review was to highlight the likely impact of important drivers of climate change on krill and Antarctic ecosystems, to discuss potential implications for CCAMLR's ecosystem-based management approach and to identify resulting future research priorities.

\section{PAST AND FUTURE CHANGES IN THE ENVIRONMENT AND THEIR IMPACT ON KRILL}

\section{Changing sea ice habitats}

There has been considerable regional variability in the trend of Antarctic sea ice extent over the past decades. In the western Antarctic Peninsula region, average monthly sea ice extent has been declining at a rate of almost $7 \%$ decade $^{-1}$ between 1979 and 2008 (Turner et al. 2009b). This trend has been counterbalanced over the past 3 decades by an increase in sea ice extent in other regions, particularly an almost $5 \%$ decade $^{-1}$ increase in the Ross Sea, leading to an overall increase in sea ice extent on the order of $1 \%$ (Stammerjohn et al. 2008, Turner et al. 2009b). For the period 1979-1998, Zwally et al. (2002) estimated an overall increase in sea ice extent by about $10950 \mathrm{~km}^{2} \mathrm{yr}^{-1}$, with a regional variability between $-1320 \mathrm{~km}^{2} \mathrm{yr}^{-1}$ in the Bellingshausen and Ammundsen Seas, and $+17600 \mathrm{~km}^{2} \mathrm{yr}^{-1}$ in the Ross Sea. This growth, however, has so far not compensated for a decline of the average sea ice coverage between 1973 and 1977, which accounted for $\sim 2 \times 10^{6} \mathrm{~km}^{2}$ (Cavalieri et al. 2003, Parkinson 2004). Reconstructions of the position of the ice edge in the pre-satellite era give strong evidence that the overall areal sea ice coverage in the Southern Ocean declined considerably during the second half of the 20th century (Turner et al. 2009a). For example, de la Mare (1997) demonstrated an abrupt $25 \%$ decline $\left(\sim 5.7 \times 10^{6} \mathrm{~km}^{2}\right)$ in Antarctic summer sea ice extent between the 1950s and 1970s based on whaling records. More important ecologically than the areal extent of ice coverage may be its duration and thickness distribution. Between 1979 and 2004, the sea ice season in the western Antarctic Peninsula region and southern Bellingshausen Sea has shortened by 85 d, i.e. at a rate of $37.7 \mathrm{~d}$ decade $^{-1}$ (our Fig. 1C; Parkinson 2004, Stammerjohn et al. 2008). This trend is consistent with a declining areal ice coverage and increasing temperatures in these regions (Turner et al. 2009b). In other regions, particularly the Ross Sea, the sea ice season has been lengthening at a rate of $23.1 \mathrm{~d}_{\text {decade }^{-1}}$ between 1979 and 2004, associated with the observed overall increase of areal ice coverage in this region (Parkinson 2004, Stammerjohn et al. 2008).

Only recently, reliable circumpolar ice thickness distributions have been generated for the Antarctic, averaged over the period 1981-2005 (Worby et al. 2008). These data show that the western Weddell Sea (between 45 and $60^{\circ} \mathrm{W}$ ), an area of high krill abundance and key target region for fishing, has the highest annual mean ice thickness, but also the highest variability in ice thickness compared to other regions of the Antarctic sea ice zone. Long-term trends in ice thickness of the Southern Ocean, however, are not yet available. Warning signs come from the Arctic Ocean, where average ice thickness may have decreased by up to $42 \%$ between the periods of 1958-1976 and 1993-1997, concomitant with a significant decline of the areal extent of sea ice (Rothrock et al. 1999). The regionally divergent trends in the 
duration and extent of Antarctic sea ice coverage may temporarily have masked a negative circumpolar trend. In the course of the 21st century, air temperatures in the Antarctic region are predicted to further increase (IPCC 2007). As climate warming continues, coupled ice-ocean-atmosphere models predict a $33 \%$ decrease in the areal extent of Antarctic winter sea ice by the end of this century (Bracegirdle et al. 2008).

Krill are associated with sea ice at all stages of their life cycle (Marschall 1988, Hamner et al. 1989, Daly 1990, Siegel et al. 1990, Flores et al. 2012). Probably the most striking evidence of this association, integrating a complexity of ice-krill interactions, is the known positive relationship of krill abundance with winter sea ice extent (Atkinson et al. 2004).

Larval krill depend on sea ice biota as a food source, because they have no capacity to store energy from food taken up during autumn phytoplankton blooms (Meyer et al. 2002, 2009, Daly 2004). When the duration of the sea ice season changes, this dependency is particularly critical, because the timing of ice formation at a specific latitude significantly determines food availability in winter sea ice (Quetin et al. 2007). Sea ice also offers a structured habitat with pressure ridges and rafted ice floes, which can retain larvae in favourable conditions, transport developing juvenile krill and protect them from predators (Meyer et al. 2009). For example, the timing of break-off and transport of sea ice can be decisive to the recruitment of juvenile krill from the Scotia Sea to the South Georgia region (Fach et al. 2006, Fach \& Klinck 2006, Thorpe et al. 2007). Important spawning grounds are located in areas of fastest sea ice loss, such as the Bellingshausen, Amundsen and Southern Scotia Seas (Hofmann \& Husrevoglu 2003, Schmidt et al. 2012). A southward redistribution of spawning grounds is limited by the Antarctic shelf, because the development of krill eggs towards the first feeding stage involves sinking to 700 to $1000 \mathrm{~m}$ water depth (Marr 1962, Hempel 1979, Quetin \& Ross 1984). Declining sea ice may thus impact krill recruitment due to multiple and probably cumulative effects. These include the role of sea ice as a shelter, as a feeding ground, and as a transport platform for larvae.

Post-larval krill survive winter by using a variety of strategies, including reduced metabolism, shrinkage and lipid storage, as well as utilisation of food sources other than phytoplankton, such as zooplankton, ice algae and seabed detritus (e.g. Kawaguchi et al. 1986, Meyer et al. 2010, Schmidt et al. 2011). In winter, due to metabolic depression, they feed opportunistically at low rates under sea ice and/or at the benthos. This energy input, even at low rates, complements reduced metabolism and lipid utilisation and is a requirement for successfully reproducing in the subsequent spring (Meyer et al. 2010, Meyer 2011). Juvenile krill do not have the storage capacity and metabolic plasticity of their adult congeners, and are thought to depend more on sea ice biota (Atkinson et al. 2002). In midwinter, the underside of sea ice was found to attract both juvenile and adult krill (Flores et al. 2012), while adults were also observed at depths $>150 \mathrm{~m}$ (Lawson et al. 2008), demonstrating the highly variable nature of krill distribution during this season. This also means that changes in the structural composition and extent of sea ice will disproportionally impact larvae and juveniles. In older krill, winter survival may be enhanced by a longer open water season, allowing them to build up more energy reserves feeding on phytoplankton.

Ice algae are most productive during spring and early summer. Krill can take advantage of this productivity and concentrate under sea ice, along with a variety of other species (Brierley et al. 2002, Flores et al. 2011, 2012). As melting proceeds, sea ice releases algae and nutrients into the water, stimulating intense phytoplankton blooms in the marginal ice zone (Hempel 1985). It is these sea ice-induced blooms that play a key role in the summer feeding of krill and have been suggested to sustain large populations of top predators (Hempel 1985, Perissinotto et al. 1997). Also deep within ice-covered areas, a large portion of krill populations can aggregate in the ice-water interface layer, supporting a food chain of major importance, as shown by year-round high abundances of krill and top predators deep in the pack-ice (van Franeker et al. 1997, Brandt et al. 2011, Flores et al. 2012). The total area of ice algae grazing grounds and ice edge blooms is likely to shrink, and the distribution of these areas will move southwards. A southward shift of the winter sea ice zone will reduce ice algal productivity due to lower light availability at higher latitudes.

In summary, sea ice has multiple benefits for krill, and reductions in duration, extent and geographical distribution of this winter habitat will likely have additive cumulative negative effects, all impacting the reproductive success and survival of krill, with possible cascading effects on food web structure. If declines in the spatial and seasonal coverage of sea ice remain concentrated in the main population centre of krill and key recruitment areas as predicted, sea ice retreat may become a dominant driver of krill decline. 


\section{Ocean warming}

The waters of the largest ocean current on Earth, the Antarctic Circumpolar Current (ACC), have warmed more rapidly than the global ocean as a whole. Reported mid-depth Southern Ocean temperatures have risen by $0.17^{\circ} \mathrm{C}$ between the $1950 \mathrm{~s}$ and the 1980s (Gille 2002; our Fig. 1D), and surface water temperatures west of the Antarctic Peninsula rose more than $1{ }^{\circ} \mathrm{C}$ between 1951 and 1998, associated with increased upper-layer stratification (Meredith \& King 2005). At South Georgia, the mean temperature in the top $100 \mathrm{~m}$ of the water column has increased by $0.9^{\circ} \mathrm{C}$ in January and $2.3^{\circ} \mathrm{C}$ in August over the past $80 \mathrm{yr}$ (Whitehouse et al. 2008).

Model predictions of the Southern Ocean surface water temperature increase by 2100 are small compared with those projected in surface air temperature, because the heat capacity of the ocean is larger than that of the atmosphere (Bracegirdle et al. 2008). According to Turner at al. (2009a), summer sea-surface temperatures (SSTs) south of $60^{\circ} \mathrm{S}$ are likely to be between 0.50 and $1.25^{\circ} \mathrm{C}$ warmer in 2100 than at present. In winter, SSTs are likely to range between up to $1.00^{\circ} \mathrm{C}$ warmer or $-0.25^{\circ} \mathrm{C}$ cooler than they are at present, with inherent regional variability. Significant warming $(0.75$ to almost $2.00^{\circ} \mathrm{C}$ in all seasons) is predicted at the surface between 40 and $60^{\circ} \mathrm{S}$, in the core region of the ACC. Regardless of season, the bottom waters from the surface down to $4000 \mathrm{~m}$ along the continental margin are expected to warm by $\sim 0.25^{\circ} \mathrm{C}$, with the possibility of warming by up to $0.50^{\circ} \mathrm{C}$ or slightly more at depths of 200 to $500 \mathrm{~m}$. The Southern Ocean, however, remains one of the regions where the largest differences are found between models and observations, and among different models.

As a polar marine species, Antarctic krill have adapted to low, stable temperatures reflecting the fact that conditions have been cool since the opening of the Drake Passage 39 to 35 million years ago. Given that there is only a difference of $\sim 7^{\circ} \mathrm{C}$ between the coldest and the warmest habitats in the distributional range of krill, changes on the order of 1 to $2^{\circ} \mathrm{C}$ are likely to have a significant impact on the physiological performance, distribution and behaviour of krill. The response of krill to warmer water is likely to operate at a number of levels, of which the earliest signals will be seen at the level of genomic expression, through to physiological function, and ultimately to growth and production within populations. As stenotherm crustaceans, krill are unlikely to tolerate large oscillations in temperature outside of the main range of their habitat (winter water temperatures ranging from -1 to $+1^{\circ} \mathrm{C}_{i}$ Mackey et al. 2012). Signs of stress will become most evident at their northern distributional limits, such as in the region of South Georgia (Fig. 2), where mean summer temperatures in the $0-100 \mathrm{~m}$ layer have warmed $\sim 0.9$ to $3.5^{\circ} \mathrm{C}$ over the last $80 \mathrm{yr}$ (Whitehouse et al. 2008). Although krill are able to tolerate such temperatures over short time scales (McWhinie \& Marciniak 1964, Hirche 1984), temperatures $>3.5^{\circ} \mathrm{C}$ are unlikely to be tolerable over the longer term, as shown by an increasing penalty of reduced in situ growth above an optimal temperature of range 0.5 to $1^{\circ} \mathrm{C}$ (Atkinson et al. 2006, Tarling et al. 2006). Conversely, growth and survival of adult krill may benefit from increasing water temperatures through increased metabolic rates and better food availability in colder waters. Krill may also react behaviourally to warmer surface waters by remaining in deeper waters (Schmidt et al. 2011), and this

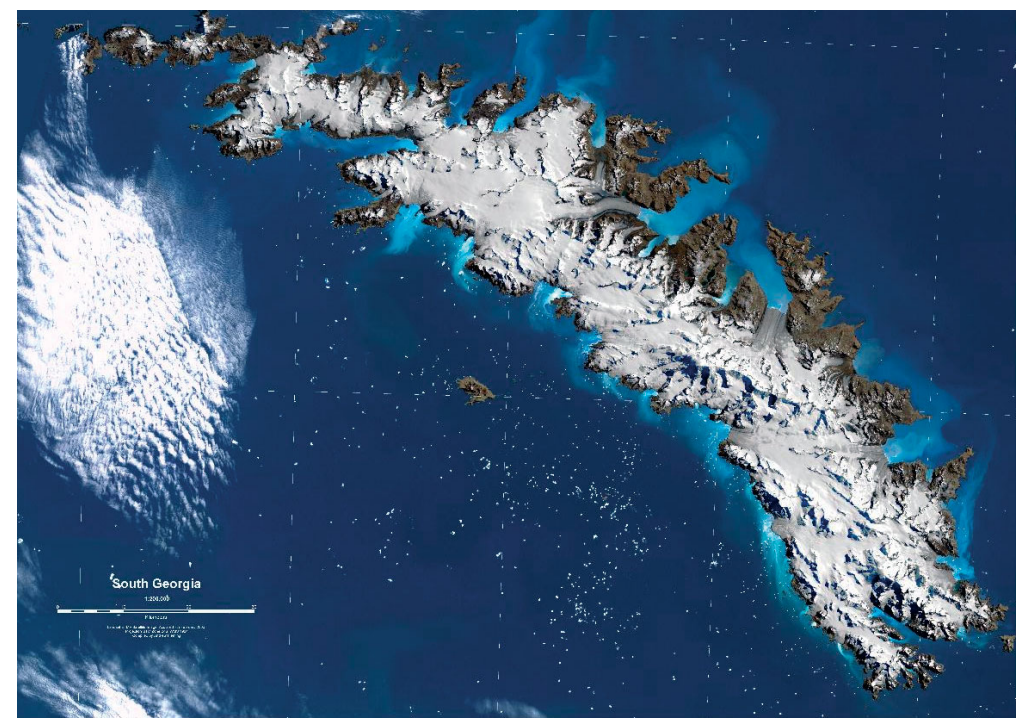

Fig. 2. Satellite image of the mountainous island of South Georgia disgorging plumes of glacial flour into the ocean (from Young et al. 2011, with permission; () Elsevier Ltd. 2011). South Georgia currently represents the warmest, northernmost outpost of the krill habitat. The productive waters around the island support a rich and diverse fauna, including higher predator species. However, substantial warming of the surface waters recorded over the last 80 yr raise questions over how long this ecosystem will remain krill-dominated. Future predictions are difficult. While warming may pose physiological stress on krill, they could avoid warm surface layers by feeding at the sea floor (Schmidt et al. 2011), and the increased glacial melt and runoff could enhance iron fertilisation of their algal food supply 
could have a marked effect on air-breathing predators that depend on krill for food.

Future thermal stress on krill populations may occur both through a gradual increase in the mean temperature (Whitehouse et al. 2008) and through an increase in the frequency of climatic anomalies, such as the El Niño Southern Oscillation (ENSO) and the Southern Annular Mode (SAM; Murphy et al. 2007, Whitehouse et al. 2008). Both may have a significant impact on the northern distributional limits of krill. The viability of presently krill-rich regions such as South Georgia as future krill habitats may be challenged in light of predicted southward shifts in distributional limits of zooplankton (Mackey et al. 2012).

Ocean warming will have both positive and negative effects on krill, depending on the geographical region and the effect of increasing water temperatures on their food sources, competitors and predators. It is likely, however, that with rising water temperatures the balance is shifted more and more towards negative effects, and will result in a southward shift in the distribution change. Due to lower limited physiological plasticity relative to adults, these negative effects will strike most profoundly on early developmental stages, thereby affecting recruitment.

\section{Changing circulation patterns}

The changes evident in air temperature (Meredith \& King 2005), water temperature (Gille 2002) and ice dynamics (Stammerjohn et al. 2008) reflect responses of the oceanic circulation to extra-tropical and regional forcing induced by climate change (Fyfe \& Saenko 2006, Böning et al. 2008). Increased westerly winds resulting from Antarctic ozone depletion contribute to a positive phase of the SAM (Lovenduski \& Gruber 2005, Cai 2006). This increase in the SAM has resulted in both increased poleward heat transport through upwelling of Upper Circumpolar Deepwater, and southward displacement of the fronts within the ACC (Gille 2002). Tele-connections with global climate patterns, such as the ENSO, also act upon this increase in westerly winds (Turner et al. 2005, Harangozo 2006). Together these factors are largely responsible for changes in circulation patterns and oceanography that will have both positive and negative effects on the growth, survival and recruitment of krill, as well as Antarctic ecosystems.

On the one hand, increased wind speeds and stronger ENSO events may trigger better nutrient advection, increase connectivity of krill populations and enhance transport of larvae into feeding grounds. For example, the strength of the Weddell Gyre is linked to ENSO events. During El Niño, the Weddell Gyre strengthens, potentially increasing transport of the coastal boundary current near the Antarctic Peninsula. During La Niña, the opposite pattern occurs. Increased transport of the colder, more saline Weddell Shelf Water may contribute iron from the shelf to the Antarctic Peninsula area and the Weddell-Scotia Confluence, impacting dynamical balances and productivity, supporting krill growth during summer and recruitment of early larvae to surface waters.

On the other hand, changes in stratification patterns may change phytoplankton composition and productivity, reducing food availability for krill and exporting larvae out of favourable conditions. Changes in heat flux and eddy energy will affect the mixed layer depths and stratification in the ACC in many areas of the Southern Ocean (Law et al. 2003, 2006). This will directly impact the vertical flux of nutrients and limiting elements (e.g. iron) into the euphotic zone. Along the western Antarctic Peninsula, phytoplankton community structure is already thought to have changed owing to impacts of climate change (Montes-Hugo et al. 2009). Changes in mixed layer depth in response to climate forcing will affect the spatial distribution of production and the phytoplankton community structure, and therefore can affect krill populations.

Which of these effects prevails is likely to vary considerably among regions, depending on local hydrography and bathymetry. Both the sign and the magnitude of their combined effect on krill population size are far from clear. The dominant paradigm for interpreting the population dynamics of krill, particularly in the South Atlantic, is that recruitment into an area is determined by the flux of krill adults and larvae from areas 'upstream' in the ACC (Murphy et al. 2004b). If this is the case, then changing circulation patterns may well have a dominating effect on the distribution and abundance of krill and on their availability to predators. There is, however, evidence that krill populations may have centres of distribution that are associated with quasi-stationary circulation patterns and that self-recruitment may occur in these regions (Nicol 2006). Climate change and fishing practices would affect krill populations differently, if they were resident in an area as opposed to just passing through. Deciphering the relationship between krill populations and currents is thus critical for understanding change and managing the fishery. 


\section{Ocean acidification}

The ecosystems of the Southern Ocean are expected to be some of those most severely affected by ocean acidification (OA) because of the higher solubilities of $\mathrm{CO}_{2}$ and $\mathrm{CaCO}_{3}$ in cold waters, and because of regional upwelling of hypercapnic deep-sea water (Sabine et al. 2004, Doney et al. 2009). Atmospheric $\mathrm{CO}_{2}$ concentration has risen from $280 \mathrm{ppm}$ in the preindustrial period to presently $\sim 380 \mathrm{ppm}$ (Orr et al. 2005). Although future projections for atmospheric $\mathrm{CO}_{2}$ level are highly variable among the scenarios discussed by the Intergovernmental Panel on Climate Change (IPCC), atmospheric $\mathrm{CO}_{2}$ concentrations are projected to increase throughout the 21st century according to all scenarios. The IPCC marker scenarios project atmospheric $\mathrm{CO}_{2}$ concentrations ranging from 535 to 983 ppm by 2100 (IPCC 2007). Recent studies based on in situ time series provide evidence of $\mathrm{OA}$ already progressing in extensive regions of the Southern Ocean (Midorikawa et al. 2012). In the Southern Ocean, model-based projections of $\mathrm{CO}_{2}$ concentrations in seawater expressed as partial pressure $\left(\mathrm{pCO}_{2}\right)$ and measured in $\mu a t m$ (1 $\mu \mathrm{atm}=1 \mathrm{ppm}$ in air), suggest that surface water $\mathrm{pCO}_{2}$ levels may reach 584 and $870 \mu$ atm by 2100 in the Scotia Sea and the Weddell Sea, respectively. At greater depths, levels may exceed 1000 patm by 2100 , and even reach nearly $\sim 1400 \mu \mathrm{atm}$ in the Weddell Sea region at a depth of 300 to $500 \mathrm{~m}$ (Kawaguchi et al. 2011b). There will further be a seasonal variation in the concentration of $\mathrm{CO}_{2}$ in surface seawater (McNeil \& Matear 2008). There are also likely considerable regional differences in $\mathrm{CO}_{2}$ levels at surface and at depth, with some of the largest increases being projected for areas where a large portion of the krill population lives (S. Kawaguchi et al. unpublished data).

Studies on the effects of OA on animals are in their infancy. However, there has been a range of reported responses by organisms to elevated $\mathrm{pCO}_{2}$ concentrations, from a variety of habitats (Hofmann et al. 2010, Schiermeier 2011). OA is likely to have biochemical and physiological effects on krill, but it will also affect other elements of the food chain (Orr et al. 2005, Fabry et al. 2008). These changes may have further ramifications for krill. The partial pressure of $\mathrm{CO}_{2}$ generally increases with depth. Thus, animals such as krill that routinely make extensive vertical migrations will spend much of their life exposed to higher and more variable levels of OA than organisms living mostly in surface waters (Kawaguchi et al. 2011b). The only published research on the effects of OA on krill suggests that, at high levels of $\mathrm{CO}_{2}$

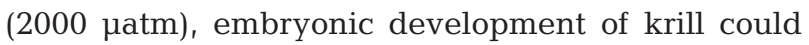
be arrested (Kawaguchi et al. 2011b). Preliminary results from long-term experiments on krill (S. Kawaguchi et al. unpublished data), as well as published information on other crustacean species (Whiteley 2011), suggest that growth, survival and recruitment of young krill could also directly and/or indirectly be affected by increased $\mathrm{pCO}_{2}$. Increasing $\mathrm{CO}_{2}$ concentrations in seawater will compromise diffusion of $\mathrm{CO}_{2}$ across gills, which leads to increased acidity in the haemolymph, incurring physiological adjustment. These acid-base adjustments are likely to be metabolically expensive in the long term (Whiteley 2011). For example, elevated $\mathrm{CO}_{2}$ concentrations and higher temperature have been shown to compromise the aerobic scope and swimming ability of penaeid shrimps (Dissanayake \& Ishimatsu 2011). Krill are active pelagic schooling animals (Hamner \& Hamner 2000); therefore, their respiratory performance is critical to their pelagic lifestyle.

OA-related changes to the functions of enzymes may also lead to higher-level physiological effects, affecting processes such as growth, moult and reproduction. As krill produce a new exoskeleton regularly throughout their lives, they are dependent on physiological and chemical processes that allow efficient uptake of calcium and other elements from seawater to form the exoskeleton. It is still unclear whether the net calcification rate of the chitinousmineralised crustacean exoskeleton will be adversely affected by the predicted magnitude of OA during this century. Potential effects on crustacean exoskeleton calcification could either influence precipitation of $\mathrm{CaCO}_{3}$, or interfere with post-moult calcification of the new exoskeleton.

In summary, the embryonic development of krill may be affected by OA in some regions in the future. In larvae and post-larvae, the acid-base regulation may compromise their somatic growth, reproduction, fitness and behaviour. To date it is unclear at which level of OA severe effects on the population level can be expected. It is therefore important to start/continue sustained observations of population and condition parameters of krill at circumpolar scales in order to detect potential effects of $\mathrm{OA}$ in the future.

\section{Elevated UV radiation}

Stratospheric ozone over Antarctica is predicted to recover from near-depletion during the second half 
of the current century (around 2060). As long as the ozone layer has not fully recovered, UV radiation is likely to act as an additional environmental stressor on krill and Antarctic ecosystems. Over the last few decades there has been a considerable zonal asymmetry in total ozone distribution over Antarctica due to planetary waves in the polar stratosphere (Evtushevsky et al. 2008). In Antarctic spring (September to November), the minimum of the quasi-stationary wave (QSW) in total ozone distribution is continuously located over the Antarctic Peninsula and Weddell Sea area, where the major part of the krill population resides. The quasi-stationary minimum in ozone distribution over the northern Weddell Sea area can increase sea surface UV irradiation in comparison to the Ross Sea and East Antarctica, where low UV radiation exists in spring.

Elevated UV radiation is known to impact marine organisms (Karentz 1991, Naganobu et al. 1999, Karentz \& Bosch 2001). The direct impact of UV-B on the krill population can occur through genetic damage (Jarman et al. 1999, Dahms et al. 2011), physiological effects (Newman et al. 1999, 2000) or through behavioural reactions (Newman et al. 2003). Indirect effects can arise through declines in primary productivity caused by increased UV radiation and changes in the structure of food webs.

\section{CHANGES IN KRILL AND FISHERIES}

\section{Changes in krill populations}

About $75 \%$ of the circumpolar krill population live in the Atlantic sector 0 to $90^{\circ} \mathrm{W}$ (our Fig. $1 \mathrm{~A}$; Atkinson et al. 2008). Within this sector, several lines of evidence suggest that the abundance, recruitment success and population structure of krill have all shown significant changes since the 1970s (Fig. 3A; see also Loeb et al. 1997, Reid \& Croxall 2001, Fraser \& Hofmann 2003, Atkinson et al. 2004, Trivelpiece et al. 2011). Mean population density tended to decrease over these decades (Fig. 3A), concomitantly with a statistically significant increase in mean krill length, from 37 to $44 \mathrm{~mm}$ (A. Atkinson et al. unpublished data: www.iced.ac.uk/science/krillbase.htm). Whether this is an ongoing trend, however, is a subject of active research.

It should be taken into account that no directional trends in population size, recruitment or sea ice links have been established outside the Atlantic sector. This may be due to the absence of time series of sufficient duration, although it is likely that processes affecting krill distribution and abundance may vary regionally. It is worth noting that large tracts of this habitat are conducive to krill growth (Atkinson et al.
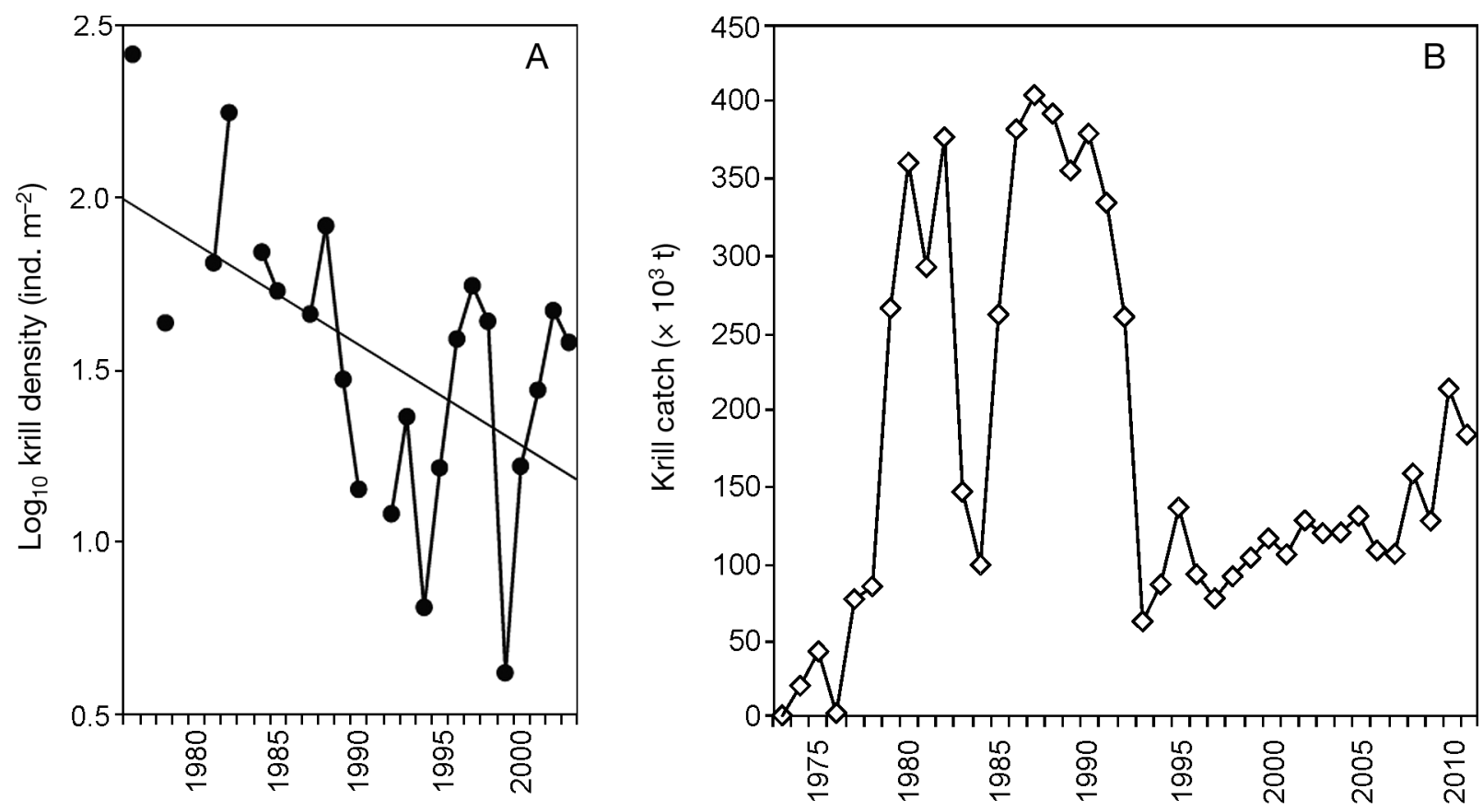

Fig. 3. Euphausia superba. (A) Change in mean density of post-larval krill (ind. $\mathrm{m}^{-2}$ ) within the SW Atlantic sector $\left(30\right.$ to $\left.70^{\circ} \mathrm{W}\right)$ between 1976 and 2003. Based on the post-1976 dataset there is a significant decline: $\log _{10}$ (krill density) $=60.07-0.0294(\mathrm{yr})$; $\mathrm{R}^{2}=31 \%, \mathrm{p}=0.007, \mathrm{n}=22 \mathrm{yr}$ (modified from Atkinson et al. 2008; @ Inter-Research 2008). (B) Reported krill catches (in metric tonnes) in FAO Statistical Area 48, 1973 to 2011 (CCAMLR 2010, 2011b) 
2008) and may become increasingly viable habitat, for example if Ross Sea winter sea ice continues to expand in this productive sector (Fig. 1C).

Within the present day population centre of the SW Atlantic sector, the available time series of data from nets, acoustics and predators show considerable (10-fold) inter- and intra-annual variation in krill abundance (Fig. 1A). This inter-annual variability in abundance is thus of similar overall magnitude to the overall trend observed in some of the time series. Inter-annual changes correlate most clearly with sea ice variability, indicating strong environmental control on the early life cycle and thus on recruitment success and population size of krill (Kawaguchi \& Satake 1994, Siegel \& Loeb 1995, Atkinson et al. 2004, Murphy et al. 2004a, Loeb et al. 2009).

Krill have a life cycle that is closely attuned and adapted to the physical environment (Nicol 2006). One predicted outcome of habitat warming is the poleward relocation of species and assemblages (Beaugrand et al. 2002, Mackey et al. 2012). The consequences of such a range extension, for example a blocking effect of the Antarctic continental shelf, disruption of the oceanic life cycle and increased competition with Euphausia crystallorophias on the Antarctic shelf, clearly need to be addressed. Future refugia have been suggested, such as the large embayments of the Ross and Weddell Seas (Siegel 2005), but because these are not part of the ACC, the life cycle closure mechanisms would need to be fundamentally different from those of the present day.

Species in a changing environment may also be able to adapt or modulate their behaviour so that they can remain in a particular area. Adult krill are an inherently flexible species and can exist in different aggregation states, including dense swarms, super swarms, low-density diffuse layers and as individual animals (e.g. Miller \& Hampton 1989a,b, Tarling et al. 2009, Nowacek et al. 2011), they can use a wide variety of food sources (Schmidt et al. $2006,2011,2012)$, and they can express various overwintering strategies (Quetin et al. 2003, Meyer et al. 2009, Flores et al. 2012). They may also be able to use their flexible behaviour to buffer their physiological sensitivity, e.g. to small temperature increases or $\mathrm{pH}$ changes. Interestingly, it was found that krill are not restricted to surface waters but can visit the seafloor down to $3500 \mathrm{~m}$ (Takahashi et al. 2003, Clarke \& Tyler 2008, Kawaguchi et al. 2011a, Schmidt et al. 2011). During years when surface krill have been scarce at South Georgia (e.g. 1983, 2009), krill have been observed near the seafloor (Heywood et al. 1985, Main et al. 2009, Schmidt et al. 2011) and can appear in the diet of skates (Main \& Collins 2011). This suggests that these krill can respond to adversely warm surface conditions by remaining in deeper, cooler water layers. This example points to the possibility for more subtle responses of species to changing conditions, with some parts of the food web being the beneficiaries, and others the victims of climate change.

Predictions of future krill distributions based on correlations with environmental variables do not take into account the potential for krill to persist through resilience and adaptation. Given that most of the changes considered within this article will occur over time scales on the order of $100 \mathrm{yr}$, there are relatively few generations on which evolutionary mechanisms can operate, assuming that krill live for about 4 to 7 yr. Antarctic krill have been found to show little segregation in their population structure and a high level of diversity in genes such as cox1, which is indicative of a very large population gene pool (Zane et al. 1998, Goodall-Copestake et al. 2010). As a result, it is possible that certain genes that may facilitate resilience in the face of environmental change already exist within this gene pool and may be selected for under certain circumstances. However, Antarctic krill inhabit one of the world's strongest current systems, and there is likely to be a continuous flux of individuals between regions with contrasting selective pressures. This may lower the overall likelihood of adaptation through genotypic change. Nevertheless, there are a number of other means by which gene expression may be altered without changes to the DNA sequence (Jaenisch \& Bird 2003). Such epigenetic changes can occur within a single generation through mechanisms such as DNA methylation, histone modifications and RNA interference. Epigenetic changes have been found in some other crustaceans such as Daphnia (Harris et al. 2012), which altered growth and fertility in response to environmental perturbations. Studies of the potential for epigenetic change in euphausiids, particularly in facilitating physiological adaptation, are required in the face of changing environmental conditions.

\section{Krill fishery and management}

In the 2009/2010 fishing season, the Antarctic krill fishery expanded to a level of $210000 \mathrm{t}$, after a $15 \mathrm{yr}$ period at a level of 100000 to $120000 \mathrm{t} \mathrm{yr}^{-1}$ (CCAMLR 2011b, Nicol et al. 2012; our Fig. 3B). This elevated level was maintained in the 2010/2011 season, although catches were somewhat lower (181500 t; 
CCAMLR unpubl. data). The highest catch recorded in FAO Statistical Area 48, where the fishery currently operates, was 400835 t in 1987 (Fig. 3B). The historical maximum catch for the whole CCAMLR area was $528331 \mathrm{t}$ in 1982. After 1989, large parts of the mainly Soviet-operated fishery collapsed following the demise of the USSR (Fig. 3B). These catch levels are well below the current estimates of total circumpolar biomass and annual production of krill, both of which exceed 100 million $t$ (Atkinson et al. 2009). However, concern remains over this fishery, because the current increase in krill harvesting is occurring after a period of declining krill populations in the SW Atlantic sector, and the effect of historical catch levels on krill populations and ecosystems today may be different from the situation in the 1980s (Fig. 3). Furthermore, Antarctic ecosystems may be particularly vulnerable in an era of rapid environmental change (Croxall \& Nicol 2004, Gascon \& Werner 2009).

CCAMLR sets precautionary catch limits on the krill fishery in large statistical management areas using the generalised yield model (GYM, Constable \& de la Mare 1996). The GYM is a stochastic model which tracks the simulated stock over a $20 \mathrm{yr}$ period. The model incorporates functions that specify growth, mortality, age-dependent selectivity and seasonal patterns in fishing mortality (Constable \& de la Mare 1996). The GYM is used to estimate the proportionality coefficient $\gamma$ in the equation $Y=\gamma B_{0}$ (where $Y$ is the potential yield and $B_{0}$ is an estimate of the historical pre-exploitation biomass). Then, 2 separate values of $\gamma$ are estimated by the GYM. The value $\gamma_{1}$ estimates at which level of harvesting the spawning biomass does not drop below $20 \%$ of the preexploitation median level over a 20 yr harvesting period. The value $\gamma_{2}$ estimates at which level of harvesting the median population size reaches $75 \%$ of $B_{0}$. The lower of the 2 values $\gamma_{1}$ and $\gamma_{2}$ is then chosen as the level of $\gamma$ for the calculation of the precautionary yield (Miller \& Agnew 2007). This approach requires an estimate of the pre-exploitation biomass from large-scale acoustic surveys. $B_{0}$-surveys were conducted once per management area, e.g. in 1996 for Division 58.4.1, in 2000 for Area 48 and in 2006 for Division 58.4.2. The pre-exploitation biomass $B_{0}$ used to estimate precautionary yield of the GYM represents the historical level of krill before exploitation began. As a fixed parameter, it is thus robust to future changes. However, the parameters used in the GYM, such as recruitment variability, growth and mortality, are likely to be affected by climate change. At present, the model does not account for stress induced by climate change, such as increased mortality and recruitment failure due to sea ice loss.

A further key point in this process of setting catch limits is that both the estimate of the pre-exploitation biomass and the annual catch limit do not incorporate the enormous (10-fold) inter-annual variability of krill abundance and biomass. There is thus currently no system for validating the true variability in krill biomass against the GYM, and hence no mechanism to compensate for unexpected negative effects of climate change or exceptionally poor krill years. Such limitations of the GYM have been recognised by CCAMLR. Integrated assessment models for krill are currently under development, which may also provide an opportunity to explore structural assumptions about krill dynamics (CCAMLR 2011a).

In the South Atlantic (subareas 48.1 to 48.4), current catch levels are well below the annual catch limit of 5.61 million $\mathrm{t} \mathrm{yr}^{-1}$ set by CCAMLR. To further safeguard against uncertainties, CCAMLR has adopted 'trigger levels'. These trigger levels are effective catch limits that cannot be exceeded until more robust management measures for the krill fishery have been adopted. For the South Atlantic, the trigger level is $620000 \mathrm{t}$, further distributed between subareas 48.1 and 48.4 (our Fig. 1B; Nicol et al. 2012). CCAMLR agreed to move towards a feedback approach to krill fisheries management, which will require management measures to be continuously adjusted as more information becomes available. This approach will be able to incorporate information on regional and global changes (Constable 2011).

CCAMLR instituted the CCAMLR Ecosystem Monitoring Program (CEMP) in 1985, collecting information on key krill predators to distinguish changes induced by environmental variability from those induced by fisheries (Agnew 1997, Gascon \& Werner 2009). To date, CEMP remains under development with only a small number of sites providing standardised data and with no system to convert the monitoring results into management decisions (Constable 2011). Consequently, in its current configuration, CEMP is unable to distinguish the impacts of fishing from those associated with environmental change. However, CEMP data constitute a significant source of information that has been consistently and systematically maintained over more than 20 yr. CEMP will need to evolve from its present form to include greater spatial coverage to monitor at different spatial and temporal scales (CCAMLR 2011a). The envisioned feedback management cannot be properly implemented without an effective CEMP and consideration of other time series observations of krill variability. 
The fishery currently operates year-round and throughout the South Atlantic (subareas 48.1, 48.2 and 48.3). This wide coverage means that it is a potentially huge source of high-quality information on the biological state of the krill resource. This information source has been largely under-utilised (Kawaguchi \& Nicol 2007). Future management of the krill fishery will need to make better use of fisheries-derived information. This process has already started with krill fishing vessels conducting scientific surveys and collecting samples (Krafft et al. 2011). The scientific community will need to develop procedures for the better use of data collected by fishing vessels for improved understanding of krill biology and ecology, and for the management of the fishery.

\section{ECOSYSTEM CHANGES}

Climatic changes on short and long time scales can significantly impact on Antarctic ecosystems (Constable \& Doust 2009). The most marked ecosystem changes have been observed in the SW Atlantic sector of the Southern Ocean. In this region, a pronounced change in environmental conditions, most prominently sea ice decline and climate warming, has occurred in the region where the main krill fishing grounds are located (Gascon \& Werner 2009). Signals of ecological change date back to the mid1990s, when simultaneous declines in krill stocks and increases in salp populations were linked to climate variability (Loeb et al. 1997). While krill populations may have suffered from sea ice decline, salps likely have benefited from warming surface waters during the last century (Pakhomov et al. 2002, Atkinson et al. 2004, Loeb \& Santora 2012).

These changes may be caused by perturbations of the physical environment, but also reflect changes at the lower trophic levels of the food web. In the western Antarctic Peninsula (WAP) region, net primary productivity has declined during the past 3 decades, associated with a change in phytoplankton community composition, potentially impacting negatively on krill and positively on salp grazing efficiency (McClatchie \& Boyd 1983, Moline et al. 2004, Montes-Hugo et al. 2009, Schofield et al. 2010).

In the SW Atlantic sector, changes in krill biomass, whether inter-annual or longer term, affect foraging, breeding success and population size of krilldependent predators (Croxall et al. 1999, Fraser \& Hofmann 2003, Trathan et al. 2007, 2011, 2012, Trivelpiece et al. 2011). At South Georgia, a number of predator species, including penguins, seals and whales, show responses to climate variability, with a particular species response thought to be mediated through the availability of krill (Forcada et al. 2005, Leaper et al. 2006, Trathan et al. 2006). Farther south in the Scotia Arc and in the WAP regions, penguins are also showing responses to environmental variability, presumably mediated through reduced krill availability and changing sea ice (e.g. Reid \& Croxall 2001, Forcada \& Robinson 2006, Trivelpiece et al. 2011, Lynch et al. 2012). A simple interpretation of environmentally driven change is difficult to substantiate, however, and there is increasing evidence to suggest that the effects of historical harvesting are still important (Trathan \& Reid 2009, Trivelpiece et al. 2011, Lynch et al. 2012, Trathan et al. 2012). For example, certain populations of Antarctic fur seals (Christensen 2006) and humpback whales Megaptera novaeangliae (Nicol et al. 2008, IWC 2010) have increased considerably over the past decades.

Also in the Indian Ocean and Pacific sectors of the Southern Ocean, ecosystem changes associated with changing sea ice extent and climatic conditions have been reported (Dayton 1989, Cameron \& Siniff 2004, Ainley et al. 2005, Jenouvrier et al. 2005). The changes observed in the Indian and Pacific sectors of the Southern Ocean have been related to periodic climate fluctuations, such as the Southern Oscillation Index (SOI; Jenouvrier et al. 2005, Trathan et al. 2007).

Increases in water temperature are expected to result in changes in phytoplankton community structure, which in turn are expected to cascade upwards, altering primary productivity, food web dynamics and even the structure of marine food webs (Finkel et al. 2010). This is important, because krill are regionally important grazers of the larger phytoplankton, especially diatoms (Ross et al. 2000, Garibotti et al. 2003, Haberman et al. 2003a,b). A shift in phytoplankton community structure, from diatoms to cryptophytes, has already been documented in some years near the Antarctic Peninsula (Moline et al. 2004). The shift was observed during the austral summer and was correlated in time and space with glacial meltwater runoff and reduced surface water salinities. Elevated temperatures will increase the extent of coastal meltwater zones and the seasonal prevalence of cryptophytes. This change in phytoplankton composition may enhance competition of krill with gelatinous zooplankton, such as salps (Moline et al. 2004).

Krill play a central role in several Antarctic marine ecosystems; for example, in the southern Scotia Sea, 
the biomass of krill was found to outweigh that of mesozooplankton, macroplankton and pelagic fish combined (Ward et al. 2012). This key role suggests that simplistic concepts of top-down or bottom-up control may not apply. For example, locally high grazing pressure of krill modulates phytoplankton species composition (Kopczynska 1992) and chlorophyll a concentrations (Whitehouse et al. 2008), and even specific rates of phytoplankton ammonium uptake (Whitehouse et al. 2011). In addition, there is evidence of a significant role for krill in the cycling of iron for phytoplankton (Tovar-Sanchez et al. 2007, Nicol et al. 2010, Schmidt et al. 2011).

The krill-based ecosystem is similar to ecosystems dominated by small, pelagic, planktivorous fishes that do not act merely as passive conduits of trophic perturbations but, through their own internal dynamics, impose major effects on the trophic levels both above and below. Such 'wasp-waist' ecosystems are characterised by having many species at the bottom and many at the top, but only a few dominant species at a mid-level of the food web (Bakun 2006). Waspwaist analogies are instructive in interpreting krill population fluctuations, especially in relation to climate signals such as ENSO and SAM. In particular, concepts such as expansion and contraction of distributional range, or alternation between dominant species in relation to climate signals, may be useful when conceptualising appropriate future modes of management.

While krill are currently a dominant component in the more productive mid- to high-latitude sectors of Antarctica, other herbivores prevail in warmer and less productive parts of the Southern Ocean, as well as in the productive high-latitude embayments, and on much of the continental shelf. These food chains are characterised by the dominance of copepods or salps and by other euphausiids, e.g. Euphausia crystallorophias, predated on by midwater fish. They are the most prevalent food chains in many parts of the Southern Ocean, and, overall, are responsible for most of the secondary production by metazoans (Pakhomov et al. 1996, 2002, Voronina 1998, Shreeve et al. 2005). These food chains are often based on smaller phytoplankton, such as microflagellates, which are commonly predicted to flourish in a warmer world. Hence, these 'alternative' food chains may be a glimpse of the future state of many ecosystems of the Southern Ocean.

\section{CONCLUSIONS AND RECOMMENDATIONS FOR FUTURE WORK}

Climate change has the potential to alter the structure and functioning of Antarctic ecosystems pro-

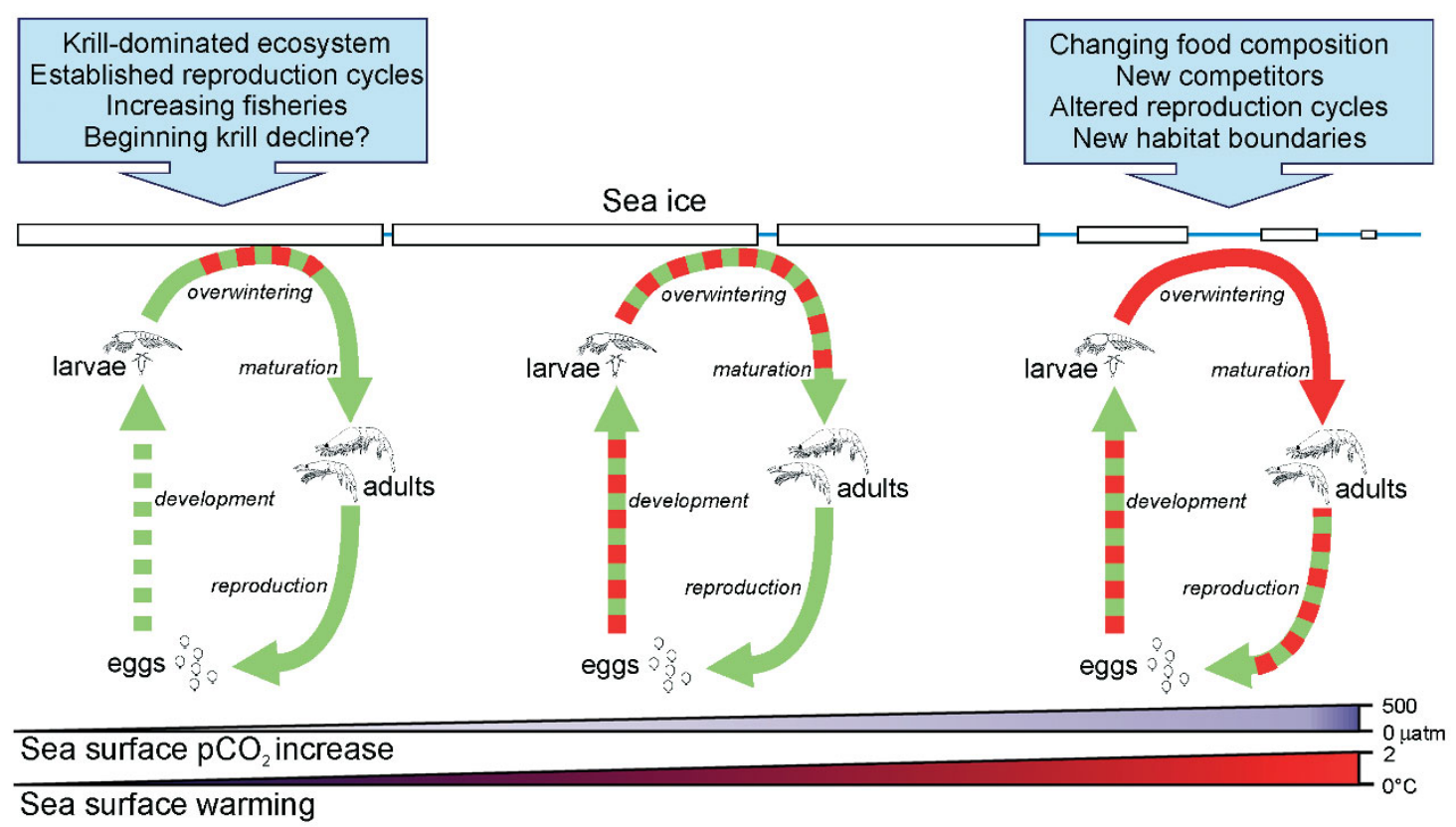

Fig. 4. Euphausia superba. Conceptual representation of the cumulative impact of climate change on the life cycle of krill in a typical krill habitat under projected scenarios for the 21st century. Key processes in the life cycle of krill are represented by green arrows. Processes under pressure of ocean warming, $\mathrm{CO}_{2}$ increase and sea ice decline are represented by red hatching, the completely red arrow indicating high risk of life-cycle interruption. The ecological position of krill may change from a present state as an ecological key species with long-established reproduction cycles to a future state, in which it faces different food sources and new competitors, demanding the adaptation of its life cycle to altered habitat conditions in new boundaries 
foundly. The impact of sea ice decline, temperature increase, acidification and circulation changes is predicted to increase considerably during the present century, whereas UV radiation levels are likely to decline. These environmental changes will act in concert to modify the abundance, distribution and life cycle of krill. For example, in a warming world, increased meltwater outflow from glaciers may enhance iron fertilisation, phytoplankton availability and thus fertility, while decreased winter sea ice may outweigh this, greatly decreasing the winter food source for the critical larval phases (Fig. 2).

Most of the environmental changes discussed here, however, are likely to impact krill negatively. Therefore their synergistic effects are also likely to be negative. Fig. 4 illustrates this and shows that recruitment, driven by the winter survival of larval and juvenile krill, is likely to be the population parameter most susceptible to these changes. This susceptibility is owed to the dependency of krill larvae on sea ice, their limited physiological flexibility and the dependency of successful recruitment on the availability of suitable spawning grounds and transport of larvae into favourable feeding grounds. With increasing impact of climate change, the adaptive capacity of krill will be increasingly challenged with changes in the physical environment, changes in the food web and new competitors. Towards the end of the 21st century, levels of warming and acidification may reach physiologically critical levels in some areas, particularly for early developmental stages (Fig. 4).

Each of the life stages of krill has a variety of 'defences' that can modulate or reduce the stresses imposed, for example behavioural flexibility or ability to adapt in situ, or to shift the distributional range to more suitable habitats. This complexity makes it dangerous to attempt predicting the future based on studies of single stressors. Flexibility and sensitivity are contrasting traits. Flexible traits include overwintering strategies, swarming, starvation resistance, seabed feeding and diet diversity. Sensitive traits include stenothermy, sea ice dependence and starvation intolerance of larvae. Simplifying the picture to identify the critical life stages most prone to future changes is a top priority.

This requirement exemplifies the power of time series analyses as a complement to process studies focussed on specific stressors. Given the intense inter-annual variability in recruitment and population size, multi-year time series help in identifying (albeit empirically) the net, overriding factors that control population dynamics. A proviso here is that abrupt regime shifts can alter empirical relationships with historically-identified drivers as the system moves from one state to the next (Loeb et al. 2009). This is most clearly illustrated in the northern hemisphere (Beaugrand 2012), making it inadvisable to project too far into the future.

CCAMLR's ecosystem-based management approach aims to ensure that any ecosystem changes associated with harvesting are reversible within 2 to 3 decades, explicitly taking into account environmental change (CCAMLR 1982). Hence, CCAMLR must develop management procedures that specifically take into account climate change effects on ecosystems, as well as on the major harvested species, krill.

In addition, a concerted scientific effort, combined with a better use of existing knowledge, is imperative, because the interactions between krill and the rest of the ecosystem are still uncertain in many critical aspects. Time series observations are fundamental to understanding the population dynamics, biology and ecology of krill. Further research on developing better methodologies for measuring krill distribution and abundance and for interpreting the results of existing studies are essential to improve our predictive abilities (Nicol \& Brierley 2010). This essential work, however, urgently needs to be complemented with research addressing a number of fundamental processes. In order of priority, the Workshop identified:

(1) recruitment processes: a mechanistic understanding of the factors that lead to successful spawning, the survival of early larvae and subsequent overwintering;

(2) the resilience and adaptation of krill when faced with environmental variability, such as changes in temperature, food availability and $\mathrm{pH}_{i}$

(3) improved estimation of the biomass of krill, taking into account inter- and intra-annual variability and their distribution in different habitats, e.g. sea floor and sea ice;

(4) the role of krill in structuring food webs;

(5) the effects of changes in the habitat of krill on their life cycle and competitiveness;

(6) improved estimation of krill consumption by predators and the level to which these predators utilise other trophic pathways.

To evaluate and improve the effectiveness of krill fisheries management, the workshop recommended complementary research on:

(1) operation of the fishery, including fisheryinduced mortality;

(2) management procedures for safeguarding krill stocks and their effectiveness;

The cumulative negative impact of climate change on krill and Antarctic ecosystems is a matter of con- 
cern to the scientific community. The changes in ecosystems, krill distribution and recruitment already observed imply that environmental change may quickly outrun the ability of current management procedures to cope with the combined effects of the fishery and climate change within the time frame mandated by CCAMLR. The responsiveness of the existing management approach needs to be enhanced, such that it can take into account effects of environmental change and intense inter-annual variability in krill recruitment and biomass, and potential interactions with the effects of an expanding fishery. To make this possible, crucial knowledge gaps need to be filled. CCAMLR is a highly progressive management organisation that, uniquely, has taken steps to safeguard the krill resource in a comprehensive fashion, long before full-scale exploitation has commenced. The future of the Southern Ocean ecosystem is intimately linked with the degree to which CCAMLR succeeds in its laudable aims. Krill have occupied a keystone position in the Antarctic ecosystem for millions of years; however, this success should, not result in complacency. The future conservation of this important species and the ecosystems of which it is part will depend on research programmes and management actions that are initiated now.

Acknowledgements. The workshop 'Antarctic Krill in a Changing Ocean' was held on the island of Texel, The Netherlands, between 11 and 15 April 2011. Funds were provided by the European Commission, DG MARE (grant agreement no. SI2.588382), the Netherlands' Polar Programme (NPP; grant no. 851.03.000), the Dutch Ministry for Economic Affairs, Agriculture and Innovation (Statutory Research Tasks Nature and Environment, Project no. WOT04-003-002) and IMARES. The workshop participants were supported by their home institutions. We particularly thank S. T. Gille, E. Maksym, J. Turner and E. F. Young for providing graphical material. We thank J. Gómez-Gutiérrez, who contributed significantly to the improvement of the manuscript. B. Aggenbach (Royal Netherlands Institute for Sea Research, NIOZ) and T. van Dalen provided logistic support.

\section{LITERATURE CITED}

Agnew DJ (1997) The CCAMLR ecosystem monitoring programme. Antarct Sci 9:235-242

Ainley DG, Clarke ED, Arrigo K, Fraser WR, Kato A, Barton KJ, Wilson PR (2005) Decadal-scale changes in the climate and biota of the Pacific sector of the Southern Ocean, 1950s to the 1990s. Antarct Sci 17:171-182

- Atkinson A, Meyer B, Stübing D, Hagen W, Schmidt K, Bathmann UV (2002) Feeding and energy budgets of Antarctic krill Euphausia superba at the onset of winterII. Juveniles and adults. Limnol Oceanogr 47:953-966

Atkinson A, Siegel V, Pakhomov E, Rothery P (2004) Long- term decline in krill stock and increase in salps within the Southern Ocean. Nature 432:100-103

Atkinson A, Shreeve RS, Hirst AG, Rothery P and others (2006) Natural growth rates in Antarctic krill (Euphausia superba): II. Predictive models based on food, temperature, body length, sex, and maturity stage. Limnol Oceanogr 51:973-987

Atkinson A, Siegel V, Pakhomov EA, Rothery P and others (2008) Oceanic circumpolar habitats of Antarctic krill. Mar Ecol Prog Ser 362:1-23

Atkinson A, Siegel V, Pakhomov EA, Jessopp MJ, Loeb V (2009) A re-appraisal of the total biomass and annual production of Antarctic krill. Deep-Sea Res I 56:727-740

Bakun A (2006) Wasp-waist populations and marine ecosystem dynamics: navigating the 'predator pit' topographies. Prog Oceanogr 68:271-288

Beaugrand G (2012) Unanticipated biological changes and global warming. Mar Ecol Prog Ser 445:293-301

Beaugrand G, Reid PC, Ibanez F, Lindley JA, Edwards M (2002) Reorganization of North Atlantic marine copepod biodiversity and climate. Science 296:1692-1694

Böning CW, Dispert A, Visbeck M, Rintoul SR, Schwarzkopf FU (2008) The response of the Antarctic Circumpolar Current to recent climate change. Nat Geosci 1:864-869

Bracegirdle TJ, Connolley WM, Turner J (2008) Antarctic climate change over the twenty-first century. J Geophys Res 113:D03103 doi:10.1029/2007JD008933

Brandt A, Bathmann U, Brix S, Cisewski B and others (2011) Maud Rise - a snapshot through the water column. Deep-Sea Res II 58:1962-1982

Brierley AS, Fernandes PG, Brandon MA, Armstrong F and others (2002) Antarctic krill under sea ice: elevated abundance in a narrow band just south of ice edge. Science 295:1890-1892

Cai W (2006) Antarctic ozone depletion causes an intensification of the Southern Ocean super-gyre circulation. Geophys Res Lett 33:L03712 doi:10.1029/2005GL024911

Cameron MF, Siniff DB (2004) Age-specific survival, abundance, and immigration rates of a Weddell seal (Leptonychotes weddellii) population in McMurdo Sound, Antarctica. Can J Zool 82:601-615

> Cavalieri DJ, Parkinson CL, Vinnikov KY (2003) 30-year satellite record reveals contrasting Arctic and Antarctic decadal sea ice variability. Geophys Res Lett 30:1970 doi:10.1029/2003gl018031

CCAMLR (Convention on the Conservation of Antarctic Marine Living Resources) (1982) Convention on the Conservation of Antarctic Marine Living Resources. CCAMLR, Hobart

CCAMLR (2010) Report of the twenty-ninth meeting of the Scientific Committee. CCAMLR, Hobart

CCAMLR (2011a) Report of the thirtieth meeting of the Scientific Committee. CCAMLR, Hobart

CCAMLR (2011b) Statistical bulletin, Vol 23 (database version). CCAMLR, Hobart. Available at www.ccamlr.org

Christensen LB (2006) Marine mammal populations: reconstructing historical abundances at the global scale. Fish Cent Res Rep 14:1-161

Clarke A, Tyler PA (2008) Adult Antarctic krill feeding at abyssal depths. Curr Biol 18:282-285

> Constable AJ (2011) Lessons from CCAMLR on the implementation of the ecosystem approach to managing fisheries. Fish Fish 12:138-151

Constable AJ, de la Mare WK (1996) A generalised model for evaluating yield and the long term status of fish stocks under conditions of uncertainty. CCAMLR Sci 3: $31-54$ 
Constable AJ, Doust S (2009) Southern Ocean Sentinel — an international program to assess climate change impacts on marine ecosystems: report of an international Workshop. Antarctic Climate and Ecosystems Cooperative Research Center (ACE-CRC), Commonwealth of Australia and WWF-Australia, Hobart

> Croxall JP, Nicol S (2004) Management of Southern Ocean fisheries: global forces and future sustainability. Antarct Sci 16:569-584

Croxall JR, Reid K, Prince PA (1999) Diet, provisioning and productivity responses of marine predators to differences in availability of Antarctic krill. Mar Ecol Prog Ser 177: 115-131

- Dahms HU, Dobretsov S, Lee JS (2011) Effects of UV radiation on marine ectotherms in polar regions. Comp Biochem Physiol C Toxicol Pharmacol 153:363-371

Daly KL (1990) Overwintering development, growth, and feeding of larval Euphausia superba in the Antarctic marginal ice zone. Limnol Oceanogr 35:1564-1576

$>$ Daly KL (2004) Overwintering growth and development of larval Euphausia superba: an interannual comparison under varying environmental conditions west of the Antarctic Peninsula. Deep-Sea Res II 51:2139-2168

- Dayton PK (1989) Interdecadal variation in an Antarctic sponge and its predators from oceanographic climate shifts. Science 245:1484-1486

de la Mare WK (1997) Abrupt mid-twentieth-century decline in Antarctic sea-ice extent from whaling records. Nature 389:57-60

> Dissanayake A, Ishimatsu A (2011) Synergistic effects of elevated $\mathrm{CO}_{2}$ and temperature on the metabolic scope and activity in a shallow-water coastal decapod (Metapenaeus joyneri; Crustacea: Penaeidae). ICES J Mar Sci 68: 1147-1154

Doney SC, Fabry VJ, Feely RA, Kleypas JA (2009) Ocean acidification: the other $\mathrm{CO}_{2}$ problem. Annu Rev Mar Sci 1:169-192

Evtushevsky OM, Grytsai AV, Klekociuk AR, Milinevsky GP (2008) Total ozone and tropopause zonal asymmetry during the Antarctic spring. J Geophys Res 113:D00B06 doi:10.1029/2008JD009881

Fabry VJ, Seibel BA, Feely RA, Orr JC (2008) Impacts of ocean acidification on marine fauna and ecosystem processes. ICES J Mar Sci 65:414-432

Fach BA, Klinck JM (2006) Transport of Antarctic krill (Euphausia superba) across the Scotia Sea. Part I: circulation and particle tracking simulations. Deep-Sea Res I 53:987-1010

> Fach BA, Hofmann EE, Murphy EJ (2006) Transport of Antarctic krill (Euphausia superba) across the Scotia Sea. Part II: krill growth and survival. Deep-Sea Res I 53: 1011-1043

Finkel ZV, Beardall J, Flynn KJ, Quigg A, Rees TAV, Raven JA (2010) Phytoplankton in a changing world: cell size and elemental stoichiometry. J Plankton Res 32:119-137

Flores H, van Franeker JA, Cisewski B, Leach H and others (2011) Macrofauna under sea ice and in the open surface layer of the Lazarev Sea, Southern Ocean. Deep-Sea Res II 58:1948-1961

- Flores H, van Franeker JA, Siegel V, Haraldsson M and others (2012) The association of Antarctic krill Euphausia superba with the under-ice habitat. PLoS ONE 7:e31775

Forcada J, Robinson SL (2006) Population abundance, structure and turnover estimates for leopard seals during winter dispersal combining tagging and photo-identification data. Polar Biol 29:1052-1062

Forcada J, Trathan PN, Reid K, Murphy EJ (2005) The effects of gl obal climate variability in pup production of Antarctic fur seals. Ecology 86:2408-2417

Fraser WR, Hofmann EE (2003) A predator's perspective on causal links between climate change, physical forcing and ecosystem response. Mar Ecol Prog Ser 265:1-15

> Fyfe JC, Saenko OA (2006) Simulated changes in the extratropical Southern Hemisphere winds and currents. Geophys Res Lett 33:L06701 doi:10.1029/2005gl025332

> Garibotti IA, Vernet M, Ferrario ME, Smith RC, Ross RM, Quetin LB (2003) Phytoplankton spatial distribution patterns along the western Antarctic Peninsula (Southern Ocean). Mar Ecol Prog Ser 261:21-39

Gascon V, Werner R (2009) Preserving the Antarctic marine food web: achievements and challenges in Antarctic krill fisheries management. In: Chircop A, Coffen-Smout S, McConnel M (eds) Ocean Yearbook, Vol 23. Martinus Nijhoff Publishers, Leiden, p 279-308

Gille ST (2002) Warming of the Southern Ocean since the 1950s. Science 295:1275-1277

> Goodall-Copestake WP, Perez-Espona S, Clark MS, Murphy EJ, Seear PJ, Tarling GA (2010) Swarms of diversity at the gene cox1 in Antarctic krill. Heredity 104:513-518

> Haberman KL, Quetin LB, Ross RM (2003a) Diet of the Antarctic krill (Euphausia superba Dana). I. Comparisons of grazing on Phaeocystis antarctica (Karsten) and Thalassiosira antarctica (Comber). J Exp Mar Biol Ecol 283: 79-95

Haberman KL, Ross RM, Quetin LB (2003b) Diet of the Antarctic krill (Euphausia superba Dana). II. Selective grazing in mixed phytoplankton assemblages. J Exp Mar Biol Ecol 283:97-113

Hamner W, Hamner P (2000) Behavior of Antarctic krill (Euphausia superba): schooling, foraging, and antipredatory behavior. Can J Fish Aquat Sci 57 (Suppl 3):192-202

- Hamner W, Hamner P, Obst B (1989) Field observations on the ontogeny of schooling of Euphausia superba furciliae and its relationship to ice in Antarctic waters. Limnol Oceanogr 34:451-456

Harangozo SA (2006) Atmospheric circulation impacts on winter maximum sea ice in the west Antarctic Peninsula region (1979-2001). Geophys Res Lett 33:L02502 doi: 10.1029/2005GL024978

> Harris KDM, Bartlett NJ, Lloyd VK (2012) Daphnia as an emerging epigenetic model organism. Genet Res Int 2012:147892 doi:10.1155/2012/147892

Hempel I (1979) Vertical distribution of eggs and nauplii of krill (Euphausia superba) south of Elephant Island. Meeresforsch Rep Mar Res 27:119-123

Hempel G (1985) Antarctic marine food webs. In: Siegfried W, Condy P, Laws R (eds) Antarctic nutrient cycles and food webs. Springer Press, Berlin, p 267-270

> Heywood RB, Everson I, Priddle J (1985) The absence of krill from the South Georgia Zone, winter 1983. Deep-Sea Res 32:369-378

Hirche HJ (1984) Temperature and metabolism of plankton. 1. Respiration of Antarctic zooplankton at different temperatures with a comparison of Antarctic and nordic krill. Comp Biochem Physiol A Mol Integr Physiol 77:361-368

- Hofmann EE, Husrevoglu YS (2003) A circumpolar modeling study of habitat control of Antarctic krill (Euphausia superba) reproductive success. Deep-Sea Res II 50: 3121-3142

> Hofmann GE, Barry JP, Edmunds PJ, Gates RD, Hutchins DA, Klinger T, Sewell MA (2010) The effect of ocean acidification on calcifying organisms in marine ecosystems: an organism-to-ecosystem perspective. Annu Rev Ecol Evol Syst 41:127-147 
IPCC (Intergovernmental Panel on Climate Change) (2007) Climate change 2007: synthesis report. Contribution of Working Groups I, II and III to the Fourth Assessment Report of the Intergovernmental Panel on Climate Change. Intergovernmental Panel on Climate Change, Geneva

IWC (International Whaling Commission) (2010) Whale population estimates. International Whaling Commission, Cambridge. Available at http://iwcoffice.org/conserva tion/estimate.htm

Jacquet J, Pauly D, Ainley D, Holt S, Dayton P, Jackson J (2010) Seafood stewardship in crisis. Nature 467:28-29

> Jaenisch R, Bird A (2003) Epigenetic regulation of gene expression: how the genome integrates intrinsic and environmental signals. Nat Genet 33:245-254

> Jarman S, Elliott N, Nicol S, McMinn A, Newman S (1999) The base composition of the krill genome and its potential susceptibility to damage by UV-B. Antarct Sci 11: 23-26

Jenouvrier S, Weimerskirch $\mathrm{H}$, Barbraud C, Park $\mathrm{YH}$, Cazelles B (2005) Evidence of a shift in the cyclicity of Antarctic seabird dynamics linked to climate. Proc R Soc Lond B Biol Sci 272:887-895

Karentz D (1991) Ecological considerations of Antarctic ozone depletion. Antarct Sci 3:3-11

Karentz D, Bosch I (2001) Influence of ozone-related increases in ultraviolet radiation on Antarctic marine organisms. Am Zool 41:3-16

Kawaguchi K, Ishikawa S, Matsuda O (1986) The overwintering strategy of Antarctic krill (Euphausia superba Dana) under the coastal fast ice off the Ongul Islands in Lützow-Holm Bay, Antarctica. Mem Natl Inst Polar Res (Jpn) 44:67-85

Kawaguchi S, Nicol S (2007) Learning about Antarctic krill from the fishery. Antarct Sci 19:219-230

Kawaguchi S, Satake M (1994) Relationship between recruitment of the Antarctic krill and the degree of ice cover near the South Shetland Islands. Fish Sci 60:123-124

Kawaguchi S, Kilpatrick R, Roberts L, King RA, Nicol S (2011a) Ocean-bottom krill sex. J Plankton Res 33: 1134-1138

Kawaguchi S, Kurihara H, King R, Hale L and others (2011b) Will krill fare well under Southern Ocean acidification? Biol Lett 7:288-291 doi:10.1098/rsbl.2010.0777

Kopczynska E (1992) Dominance of microflagellates over diatoms in the Antarctic areas of deep vertical mixing and krill concentrations. J Plankton Res 14:1031-1054

Krafft BA, Skaret G, Calise L (2011) Antarctic krill and apex predators in the South Orkney Islands area 2011, surveyed with the commercial fishing vessel Saga Sea. WGEMM CCAMLR. Convention for the Conservation of Antarctic Marine Living Resources, Hobart

Law CS, Abraham ER, Watson AJ, Liddicoat MI (2003) Vertical eddy diffusion and nutrient supply to the surface mixed layer of the Antarctic Circumpolar Current. J Geophys Res 108:3272 doi:10.1029/2002JC001604

- Law CS, Crawford WR, Smith MJ, Boyd PW and others (2006) Patch evolution and the biogeochemical impact of entrainment during an iron fertilisation experiment in the sub-Arctic Pacific. Deep-Sea Res II 53:2012-2033

- Lawson GL, Wiebe PH, Ashjian CJ, Stanton TK (2008) Euphausiid distribution along the Western Antarctic Peninsula - Part B: distribution of euphausiid aggregations and biomass, and associations with environmental features. Deep-Sea Res II 55:432-454

- Leaper R, Cooke J, Trathan PN, Reid K, Rowntree V, Payne $\mathrm{R}$ (2006) Global climate drives southern right whale
(Eubalaena australis) population dynamics. Biol Lett 2:289-292

Loeb VJ, Santora JA (2012) Population dynamics of Salpa thompsoni near the Antarctic Peninsula: growth rates and interannual variations in reproductive activity (19932009). Prog Oceanogr 96:93-107

- Loeb VJ, Siegel V, Holm-Hansen O, Hewitt R, Fraser W, Trivelpiece W, Trivelpiece S (1997) Effects of sea-ice extent and krill or salp dominance on the Antarctic food web. Nature 387:897-900

Loeb VJ, Hofmann EE, Klinck JM, Holm-Hansen O, White WB (2009) ENSO and variability of the Antarctic Peninsula pelagic marine ecosystem. Antarct Sci 21:135-148

- Lovenduski NS, Gruber N (2005) Impact of the Southern Annular Mode on Southern Ocean circulation and biology. Geophys Res Lett 32:L11603 doi:10.1029/ $2005 \mathrm{gl} 1022727$

> Lynch HJ, Naveen R, Trathan PN, Fagan WF (2012) Spatially integrated assessment reveals widespread changes in penguin populations on the Antarctic Peninsula. Ecology 93:1367-1377

> Mackey A, Atkinson A, Hill S, Ward P, Cunningham N, Johnston NM, Murphy EJ (2012) Antarctic macrozooplankton of the southwest Atlantic sector and Bellingshausen Sea: historical distributions; relationships with food; and implications for ocean warming. Deep-Sea Res II 59-60:130-146

Main CE, Collins MA (2011) Diet of the Antarctic starry skate Amblyraja georgiana (Rajidae, Chondrichthyes) at South Georgia (Southern Ocean). Polar Biol 34:389-396

> Main CE, Collins MA, Mitchell R, Belchier M (2009) Identifying patterns in the diet of mackerel icefish (Champsocephalus gunnari) at South Georgia using bootstrapped confidence intervals of a dietary index. Polar Biol 32:569-581

Marr JWS (1962) The natural history and geography of the Antarctic krill (Euphausia superba). Disc Rep 32:33-464

> Marschall HP (1988) The overwintering strategy of Antarctic krill under the pack-ice of the Weddell Sea. Polar Biol 9:129-135

- McClatchie S, Boyd CM (1983) Morphological study of sieve efficiencies and mandibular surfaces in the Antarctic krill, Euphausia superba. Can J Fish Aquat Sci 40: 955-967

McNeil BI, Matear RJ (2008) Southern Ocean acidification: a tipping point at 450-ppm atmospheric $\mathrm{CO}_{2}$. Proc Natl Acad Sci USA 105:18860-18864

McWhinie MA, Marciniak P (1964) Temperature responses and tissue respiration in Antarctic Crustacea with particular reference to the krill Euphausia superba. In: Lee MO (ed) Biology of the Antarctic seas. American Geophysical Union, Washington, DC, p 63-72

Meredith MP, King JC (2005) Rapid climate change in the ocean west of the Antarctic Peninsula during the second half of the 20th century. Geophys Res Lett 32:L19604 doi:10.1029/2005GL024042

Meyer B (2011) The overwintering of Antarktic krill, Euphausia superba, from an ecophysiological perspective. Polar Biol 35:25-37

> Meyer B, Atkinson A, Stübing D, Oettl B, Hagen W, Bathmann UV (2002) Feeding and energy budgets of Antarctic krill Euphausia superba at the onset of winter-I. Furcilia III larvae. Limnol Oceanogr 47:943-952

Meyer B, Fuentes V, Guerra C, Schmidt K and others (2009) Physiology, growth, and development of larval krill Euphausia superba in autumn and winter in the Lazarev Sea, Antarctica. Limnol Oceanogr 54:1595-1614 
Meyer B, Auerswald L, Siegel V, Spahic S and others (2010) Seasonal variation in body composition, metabolic activity, feeding, and growth of adult krill Euphausia superba in the Lazarev Sea. Mar Ecol Prog Ser 398:1-18

> Midorikawa $\mathrm{T}$, Inoue HY, Ishii M, Sasano D and others (2012) Decreasing $\mathrm{pH}$ trend estimated from 35-year time series of carbonate parameters in the Pacific sector of the Southern Ocean in summer. Deep-Sea Res I 61:131-139

Miller DGM, Agnew D (2007) Management of krill fisheries in the Southern Ocean. In: Everson I (ed) Krill: biology, ecology and fisheries. Blackwell Science, Hoboken, NJ, p 300-337

Miller DGM, Hampton I (1989a) Biology and ecology of the Antarctic krill (Euphausia superba Dana): a review. BIOMASS Sci Ser 9. SCAR \& SCOR, Scott Polar Research Institute, Cambridge

Miller DGM, Hampton I (1989b) Krill aggregation characteristics: spatial-distribution patterns from hydroacoustic observations. Polar Biol 10:125-134

Moline MA, Claustre H, Frazer TK, Schofield O, Vernet M (2004) Alteration of the food web along the Antarctic Peninsula in response to a regional warming trend. Glob Change Biol 10:1973-1980

Montes-Hugo M, Doney SC, Ducklow HW, Fraser W, Martinson D, Stammerjohn SE, Schofield O (2009) Recent changes in phytoplankton communities associated with rapid regional climate change along the Western Antarctic Peninsula. Science 323:1470-1473

Murphy EJ, Thorpe SE, Watkins JL, Hewitt R (2004a) Modeling the krill transport pathways in the Scotia Sea: spatial and environmental connections generating the seasonal distribution of krill. Deep-Sea Res II 51: 1435-1456

> Murphy EJ, Watkins JL, Meredith MP, Ward P, Trathan PN, Thorpe SE (2004b) Southern Antarctic Circumpolar Current Front to the northeast of South Georgia: horizontal advection of krill and its role in the ecosystem. J Geophys Res 109:C01029 doi:10.1029/2002JC001522

Murphy EJ, Trathan PN, Watkins JL, Reid K and others (2007) Climatically driven fluctuations in Southern Ocean ecosystems. Proc R Soc Lond B Biol Sci 274:3057-3067

Naganobu M, Kutsuwada K, Sasai Y, Taguchi S, Siegel V (1999) Relationships between Antarctic krill (Euphausia superba) variability and westerly fluctuations and ozone depletion in the Antarctic Peninsula area. J Geophys Res 104:20651-20665

> Newman SJ, Nicol S, Ritz D, Marchant H (1999) Susceptibility of Antarctic krill (Euphausia superba Dana) to ultraviolet radiation. Polar Biol 22:50-55

> Newman SJ, Dunlap WC, Nicol S, Ritz D (2000) Antarctic krill (Euphausia superba) acquire a UV-absorbing mycosporine-like amino acid from dietary algae. J Exp Mar Biol Ecol 255:93-110

> Newman SJ, Ritz D, Nicol S (2003) Behavioural reactions of Antarctic krill (Euphausia superba Dana) to ultraviolet and photosynthetically active radiation. J Exp Mar Biol Ecol 297:203-217

> Nicol S (2006) Krill, currents, and sea ice: Euphausia superba and its changing environment. Bioscience 56:111-120

> Nicol S, Brierley AS (2010) Through a glass less darklynew approaches for studying the distribution, abundance and biology of Euphausiids. Deep-Sea Res II 57:496-507

Nicol S, Worby A, Leaper R (2008) Changes in the Antarctic sea ice ecosystem: potential effects on krill and baleen whales. Mar Freshw Res 59:361-382

Nicol S, Bowie A, Jarman S, Lannuzel D, Meiners KM, Van
Der Merwe P (2010) Southern Ocean iron fertilization by baleen whales and Antarctic krill. Fish Fish 11:203-209

Nicol S, Foster J, Kawaguchi S (2012) The fishery for Antarctic krill-recent developments. Fish Fish 13:30-40 doi:10.1111/j.1467-2979.2011.00406.x

Nowacek DP, Friedlaender AS, Halpin PN, Hazen EL and others (2011) Super-aggregations of krill and humpback whales in Wilhelmina Bay, Antarctic Peninsula. PLoS ONE 6:e19173

Orr JC, Fabry VJ, Aumont O, Bopp L and others (2005) Anthropogenic ocean acidification over the twenty-first century and its impact on calcifying organisms. Nature 437:681-686

Pakhomov EA, Perissinotto R, McQuaid C (1996) Prey composition and daily rations of myctophid fishes in the Southern Ocean. Mar Ecol Prog Ser 134:1-14

Pakhomov EA, Froneman PW, Perissinotto R (2002) Salp/ krill interactions in the Southern Ocean: spatial segregation and implications for the carbon flux. Deep-Sea Res II 49:1881-1907

Parkinson CL (2004) Southern Ocean sea ice and its wider linkages: insights revealed from models and observations. Antarct Sci 16:387-400

Perissinotto R, Pakhomov EA, McQuaid CD, Froneman PW (1997) In situ grazing rates and daily ration of Antarctic krill Euphausia superba feeding on phytoplankton at the Antarctic Polar Front and the Marginal Ice Zone. Mar Ecol Prog Ser 160:77-91

Quetin LB, Ross RM (1984) Depth distribution of developing Euphausia superba embryos, predicted from sinking rates. Mar Biol 79:47-53

> Quetin LB, Ross RM, Frazer TK, Amsler MO, Wyatt-Evens C, Oakes SA (2003) Growth of larval krill, Euphausia superba, in fall and winter west of the Antarctic Peninsula. Mar Biol 143:833-843

> Quetin LB, Ross RM, Fritsen CH, Vernet M (2007) Ecological responses of Antarctic krill to environmental variability: Can we predict the future? Antarct Sci 19:253-266

Reid K, Croxall JP (2001) Environmental response of upper trophic-level predators reveals a system change in an Antarctic marine ecosystem. Proc R Soc B Biol Sci 268: 377-384

> Ross RM, Quetin LB, Baker KS, Vernet M, Smith RC (2000) Growth limitation in young Euphausia superba under field conditions. Limnol Oceanogr 45:31-43

Rothrock DA, Yu Y, Maykut GA (1999) Thinning of the Arctic sea-ice cover. Geophys Res Lett 26:3469-3472

Sabine CL, Feely RA, Gruber N, Key RM and others (2004) The oceanic sink for anthropogenic $\mathrm{CO}_{2}$. Science 305: 367-371

> Schiermeier Q (2010) Ecologists fear Antarctic krill crisis. Nature $467: 15$

Schiermeier Q (2011) Earth's acid test. Nature 471:154-156

Schmidt K, Atkinson A, Petzke KJ, Voss M, Pond DW (2006) Protozoans as a food source for Antarctic krill, Euphausia superba: complementary insights from stomach content, fatty acids, and stable isotopes. Limnol Oceanogr 51: 2409-2427

> Schmidt K, Atkinson A, Steigenberger S, Fielding S and others (2011) Seabed foraging by Antarctic krill: implications for stock assessment, bentho-pelagic coupling, and the vertical transfer of iron. Limnol Oceanogr 56: 1411-1428

Schmidt K, Atkinson A, Venables HJ, Pond DW (2012) Early spawning of Antarctic krill in the Scotia Sea is fuelled by 'superfluous' feeding on non-ice associated phytoplankton blooms. Deep-Sea Res II 59-60:159-172 
Schofield O, Ducklow HW, Martinson DG, Meredith MP, Moline MA, Fraser WR (2010) How do polar marine ecosystems respond to rapid climate change? Science 328:1520-1523

Shreeve RS, Tarling GA, Atkinson A, Ward P, Goss C, Watkins J (2005) Relative production of Calanoides acutus (Copepoda: Calanoida) and Euphausia superba (Antarctic krill) at South Georgia, and its implications at wider scales. Mar Ecol Prog Ser 298:229-239

Siegel V (2005) Distribution and population dynamics of Euphausia superba: summary of recent findings. Polar Biol 29:1-22

Siegel V, Loeb V (1995) Recruitment of Antarctic krill Euphausia superba and possible causes for its variability. Mar Ecol Prog Ser 123:45-56

Siegel V, Bergström B, Stromberg JO, Schalk PH (1990) Distribution, size frequencies and maturity stages of krill, Euphausia superba, in relation to sea ice in the northern Weddell Sea. Polar Biol 10:549-557

Stammerjohn SE, Martinson DG, Smith RC, Yuan X, Rind D (2008) Trends in Antarctic annual sea ice retreat and advance and their relation to El Niño-Southern Oscillation and Southern Annular Mode variability. J Geophys Res 113:C03S90 doi:10.1029/2007jc004269

Takahashi A, Dunn MJ, Trathan PN, Sato K, Naito Y, Croxall JP (2003) Foraging strategies of chinstrap penguins at Signy Island, Antarctica: importance of benthic feeding on Antarctic krill. Mar Ecol Prog Ser 250:279-289

Tarling GA, Shreeve RS, Hirst AG, Atkinson A, Pond DW, Murphy EJ, Watkins JL (2006) Natural growth rates in Antarctic krill (Euphausia superba). I. Improving methodology and predicting intermolt period. Limnol Oceanogr 51:959-972

Tarling GA, Klevjer T, Fielding S, Watkins $\mathrm{J}$ and others (2009) Variability and predictability of Antarctic krill swarm structure. Deep-Sea Res I 56:1994-2012

Thorpe SE, Murphy EJ, Watkins JL (2007) Circumpolar connections between Antarctic krill (Euphausia superba Dana) populations: investigating the roles of ocean and sea ice transport. Deep-Sea Res I 54:792-810

Tovar-Sanchez A, Duarte CM, Hernández-León S, SañudoWilhelmy SA (2007) Krill as a central node for iron cycling in the Southern Ocean. Geophys Res Lett 32: L11601 doi:10.1029/2006GL029096

Trathan PN, Reid K (2009) Exploitation of the marine ecosystem in the sub-Antarctic: historical impacts and current consequences. Pap Proc R Soc Tasman 143:9-14

Trathan PN, Murphy EJ, Forcada J, Croxall JP, Reid K, Thorpe SE (2006) Physical forcing in the southwest Atlantic: ecosystem control. In: Boyd IL, Wanless S, Camphuysen CJ (eds) Top predators in marine ecosystems. Cambridge University Press, Cambridge, p 28-45

Trathan PN, Forcada J, Murphy EJ (2007) Environmental forcing and Southern Ocean marine predator populations: effects of climate change and variability. Philos Trans R Soc Lond B Biol Sci 362:2351-2365

Trathan PN, Fretwell PT, Stonehouse B (2011) First recorded loss of an emperor penguin colony in the recent period of Antarctic regional warming: implications for other colonies. PLoS ONE 6:e14738

Trathan PN, Ratcliffe N, Masden EA (2012) Ecological driv- ers of change at South Georgia: the krill surplus, or climate variability. Ecography (in press) doi:10.1111/j.16000587.2012.07330.x

> Trivelpiece WZ, Hinke JT, Miller AK, Reiss CS, Trivelpiece SG, Watters GM (2011) Variability in krill biomass links harvesting and climate warming to penguin population changes in Antarctica. Proc Natl Acad Sci USA 108: 7625-7628

> Turner J, Colwell SR, Marshall GJ, Lachlan-Cope TA and others (2005) Antarctic climate change during the last 50 years. Int J Climatol 25:279-294

Turner J, Bindschadler R, Convey P, di Prisco G and others (eds) (2009a) Antarctic climate change and the environment. Scientific Committee on Antarctic Research, Cambridge

Turner J, Comiso JC, Marshall GJ, Lachlan-Cope TA and others (2009b) Non-annular atmospheric circulation change induced by stratospheric ozone depletion and its role in the recent increase of Antarctic sea ice extent. Geophys Res Lett 36:L08502 doi:10.1029/2009gl037524

van Franeker JA, Bathmann U, Mathot S (1997) Carbon fluxes to Antarctic top predators. Deep-Sea Res II 44:435-455

Voronina NM (1998) Comparative abundance and distribution of major filter-feeders in the Antarctic pelagic zone. J Mar Syst 17:375-390

Ward P, Atkinson A, Venables HJ, Tarling GA and others (2012) Food web structure and bioregions in the Scotia Sea: a seasonal synthesis. Deep-Sea Res II 59:253-266

> Whitehouse MJ, Meredith MP, Rothery P, Atkinson A, Ward P, Korb RE (2008) Rapid warming of the ocean around South Georgia, Southern Ocean, during the 20th century: Forcings, characteristics and implications for lower trophic levels. Deep-Sea Res I 55:1218-1228

- Whitehouse MJ, Atkinson A, Ward P, Korb RE, Rothery P, Fielding $S$ (2009) Role of krill versus bottom-up factors in controlling phytoplankton biomass in the northern Antarctic waters of South Georgia. Mar Ecol Prog Ser 393:69-82

Whitehouse MJ, Atkinson A, Rees AP (2011) Close coupling between ammonium uptake by phytoplankton and excretion by Antarctic krill, Euphausia superba. Deep-Sea Res I 58:725-732

- Whiteley NM (2011) Physiological and ecological responses of crustaceans to ocean acidification. Mar Ecol Prog Ser 430:257-271

Worby AP, Geiger CA, Paget MJ, Van Woert ML, Ackley SF, DeLiberty TL (2008) Thickness distribution of Antarctic sea ice. J Geophys Res 113:C05S92 doi:10.1029/2007JC 004254

> Young EF, Meredith MP, Murphy EJ, Carvalho GR (2011) High resolution modelling of the shelf and open ocean adjacent to South Georgia, Southern Ocean. Deep-Sea Res II 58:1540-1552

Zane L, Ostellari L, Maccatrozzo L, Bargelloni L, Battaglia B, Patarnello T (1998) Molecular evidence for genetic subdivision of Antarctic Krill (Euphausia superba Dana) populations. Proc R Soc Lond B Biol Sci 265: 2387-2391

Zwally HJ, Comiso JC, Parkinson CL, Cavalieri DJ, Gloersen P (2002) Variability of Antarctic sea ice 1979-1998. J Geophys Res 107:3041 doi:10.1029/2000JC000733 
Appendix 1. Addresses of authors (not including the first author)

Atkinson A: British Antarctic Survey, Natural Environment Research Council, Cambridge CB3 0ET, UK and Plymouth Marine Laboratory, Plymouth PL13DH, UK

Bravo Rebolledo E: Wageningen University, Department of Environmental Sciences, 6708 PB Wageningen, The Netherlands

Cirelli V: Fundación Vida Silvestre Argentina (FVSA), Buenos Aires

Cuzin-Roudy J: Observatoire Océanologique, LOV, Université Pierre et Marie Curie-CNRS, 06230 Villefranche-sur-mer, France

Fielding S: British Antarctic Survey, Natural Environment Research Council, Cambridge CB3 0ET, UK

Groeneveld JJ: Consultant to the Ministry of Economic Affairs, Agriculture and Innovation, 2594 AV Den Haag, The Netherlands

Haraldsson M: University of Gothenburg, Department of Marine Ecology, Kristineberg, 45178 Fiskebäckskil, Sweden Kawaguchi S: Australian Antarctic Division, Kingston, Tasmania 7050, Australia and Antarctic Climate and Ecosystems Cooperative Research Centre, Sandy Bay, Hobart, Tasmania 7001, Australia

Krafft BA: Institute of Marine Research, 5817 Bergen, Norway

Lombana A: World Wildlife Fund, Washington, DC 20037, USA

Marschoff E: Instituto Antártico Argentino, 1010 Buenos Aires, Argentina

Meyer B: Alfred Wegener Institute for Polar and Marine Research, 27570 Bremerhaven, Germany

Milinevsky G: Space Physics Laboratory, Kyiv National Taras Shevchenko University, Kyiv, Ukraine

Nicol S: Australian Antarctic Division, Kingston, Tasmania 7050, Australia and Institute of Marine and Antarctic Studies, University of Tasmania, Private Bag 129, Hobart, Tasmania 7001, Australia

Pakhomov EA: Department of Earth and Ocean Sciences, University of British Columbia, Vancouver, British Columbia V6T 1Z4, Canada

Reiss C: NOAA Fisheries, Antarctic Ecosystem Research Division, La Jolla, California 92037, USA

Rombolá E: Instituto Antártico Argentino, 1010 Buenos Aires, Argentina

Schmidt K: British Antarctic Survey, Natural Environment Research Council, Cambridge CB3 0ET, UK

Siegel V: Institute for Sea Fisheries, 22767 Hamburg, Germany

Tarling GA: British Antarctic Survey, Natural Environment Research Council, Cambridge CB3 0ET, UK

Teschke M: Alfred Wegener Institute for Polar and Marine Research, 27570 Bremerhaven, Germany

Tonkes H: Wageningen University, Department of Environmental Sciences, 6708 PB Wageningen, The Netherlands

Toullec JY: UPMC University of Paris 06, UMR 7144 CNRS, Adaptation et Diversité en Milieu Marin,

Station Biologique de Roscoff, 29682 Roscoff, France

Trathan PN: British Antarctic Survey, Natural Environment Research Council, Cambridge CB3 0ET, UK

Tremblay N: Alfred Wegener Institute for Polar and Marine Research, 27570 Bremerhaven, Germany

Van de Putte AP: Belgian Biodiversity Platform, Royal Belgian Institute for Natural Sciences, 1000 Brussels, Belgium and Laboratory of Biodiversity and Evolutionary Genomics, Catholic University Leuven, 3000 Leuven, Belgium

van Franeker JA: Institute for Marine Resources and Ecosystem Studies (IMARES), 1790 AD Den Burg (Texel), The Netherlands

Werner R: Antarctic International Policy Program, Pew Environment Group, The Pew Charitable Trusts, 8400 San Carlos de Bariloche, Rio Negro, Argentina

Werner T: Alfred Wegener Institute for Polar and Marine Research, 27570 Bremerhaven, Germany

Editorial responsibility: Christine Paetzold,

Oldendorf/Luhe, Germany
Submitted: October 4, 2011; Accepted: May 22, 2012

Proofs received from author(s): June 25, 2012 